\title{
Viscosity and Density of Molten Optical Glasses
}

\section{Leo Shartsis and Sam Spinner}

\begin{abstract}
The viscosities and densities of 22 optical glasses, representing all types produced at the National Bureau of Standards, were measured by a counterbalanced-sphere method. The densities agreed with those obtained by a volumeter method, and the viscosities showed good agreement with those obtained with a small rotation viscometer.

Expansivities calulated from density results in the temperature range $1,000^{\circ}$ to $1,200^{\circ}$ $\mathrm{C}$ showed that flints are low, 15 to 22 , barium crowns are intermediate, 22 to 37 , and borosilicate crowns are high, 34 to 40 (microns/meter) $/{ }^{\circ} \mathrm{C}$. The expansivities showed a positive correlation with the slope of the viscosity temperature curve.

The superiority of the theoretically derived Faxen correction of Stokes law over that of the empirical Francis formula was established by means of a freely falling sphere apparatus.
\end{abstract}

\section{Introduction}

The importance of the viscosity of glass in all phases of its manufacture is widely recognized. Certain useful empirical points such as the annealing temperature, softening temperature, strain point, etc., have been shown to be related to definite viscosities. In producing optical glass at this Bureau it has been found that the temperatures at which the stirring of the different kinds of optical glass is stopped and the pots removed from the furnace correspond to the same viscosity for all glasses. In addition to the practical reasons for studying viscosity, there is also the expectation that viscosity data will help to elucidate the structure of glasses.

The density of molten glasses as a function of temperature has not been investigated to any great extent. Expansivity is of interest to workers in glass and may be calculated from the change of density with temperature. As in the case of other fundamental properties, it may be expected that density studies will aid in determining the structure of glasses. In addition to its intrinsic interest, density data are necessary in the calculation of certain other properties, such as kinematic viscosity, some methods of measuring surface tension, etc.

\section{Glasses Tested}

The optical glasses tested were those regularly produced by the Bureau glass plant. Table 1 gives the compositions as computed from the proportions of the raw materials in the batch. The first column identifies the glass according to itts optical type, refractive index, and $A b b e^{1}$ value. Thus, F 5795/410 means a flint glass with a refractive index $N_{D}=$ 1.5795 , and Abbe value $\nu=41.0$.

Although these compositions are considered fairly reliable because each pot holds from 900 to 1,500 lb. of glass, the computations neglect small amounts of material that are dissolved from the pot. Pot attack introduces chiefly silica and alumina into the glass, the amounts varying with the corrosiveness of the glass. The practice of adding cullet (broken

1 The Abbe value $\nu=\left(N_{D}-1\right) /\left(N_{F}-N_{C}\right)$, where $N_{D}$ is the refractive index for the sodium $D$ line, and $N_{F}$ and $N_{C}$ are refractive indices for the hydrogen $F$ and $C$ lines, respectively. glass from previous melts of the same composition) also introduces variations in composition. An allcullet melt usually has a measurably higher viscosity along with lower density and refractive index than an all-batch melt because the former has dissolved more of the pot materials.

\section{Measurement of Viscosity}

\section{Sphere Method}

(a) Apparatus

Figure 1 shows a diagrammatic view of the apparatus. A platinum sphere $1.5 \mathrm{~cm}$ in diameter is suspended by a thin platinum wire fastened by a thin chain to the center of the left-hand pan of an analyt-

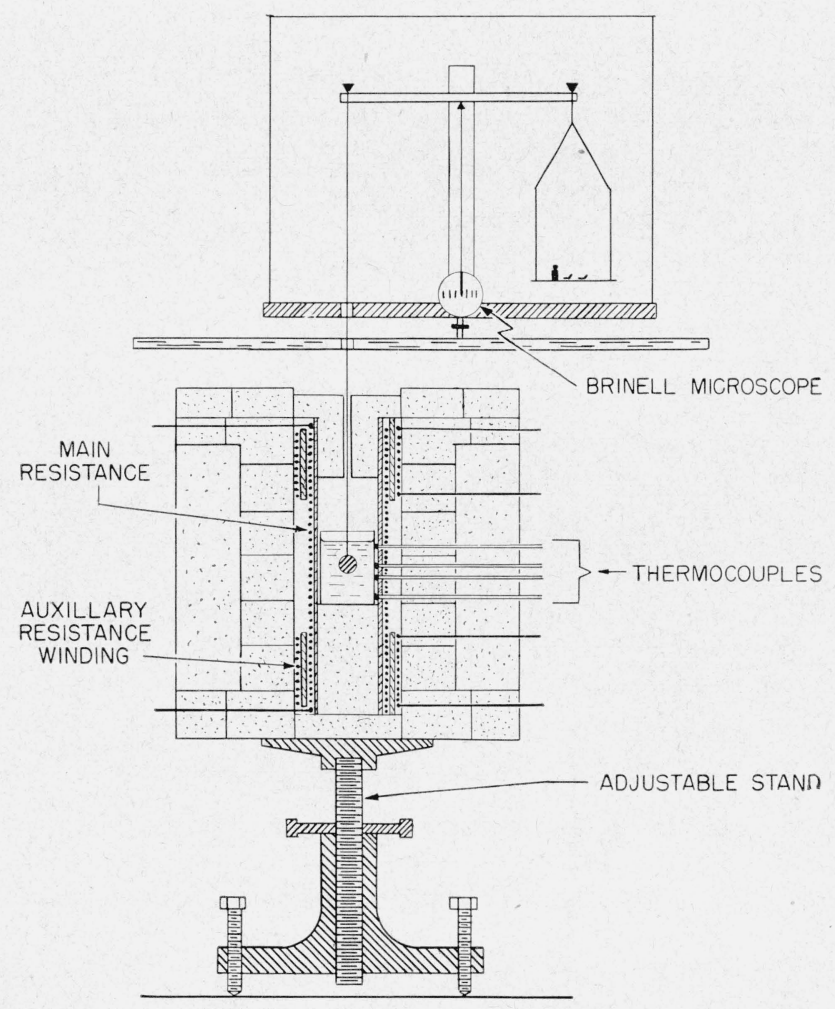

Figure 1. Restrained sphere apparatus. 
TABLE 1. Compositions of optical glasses, computed from batch

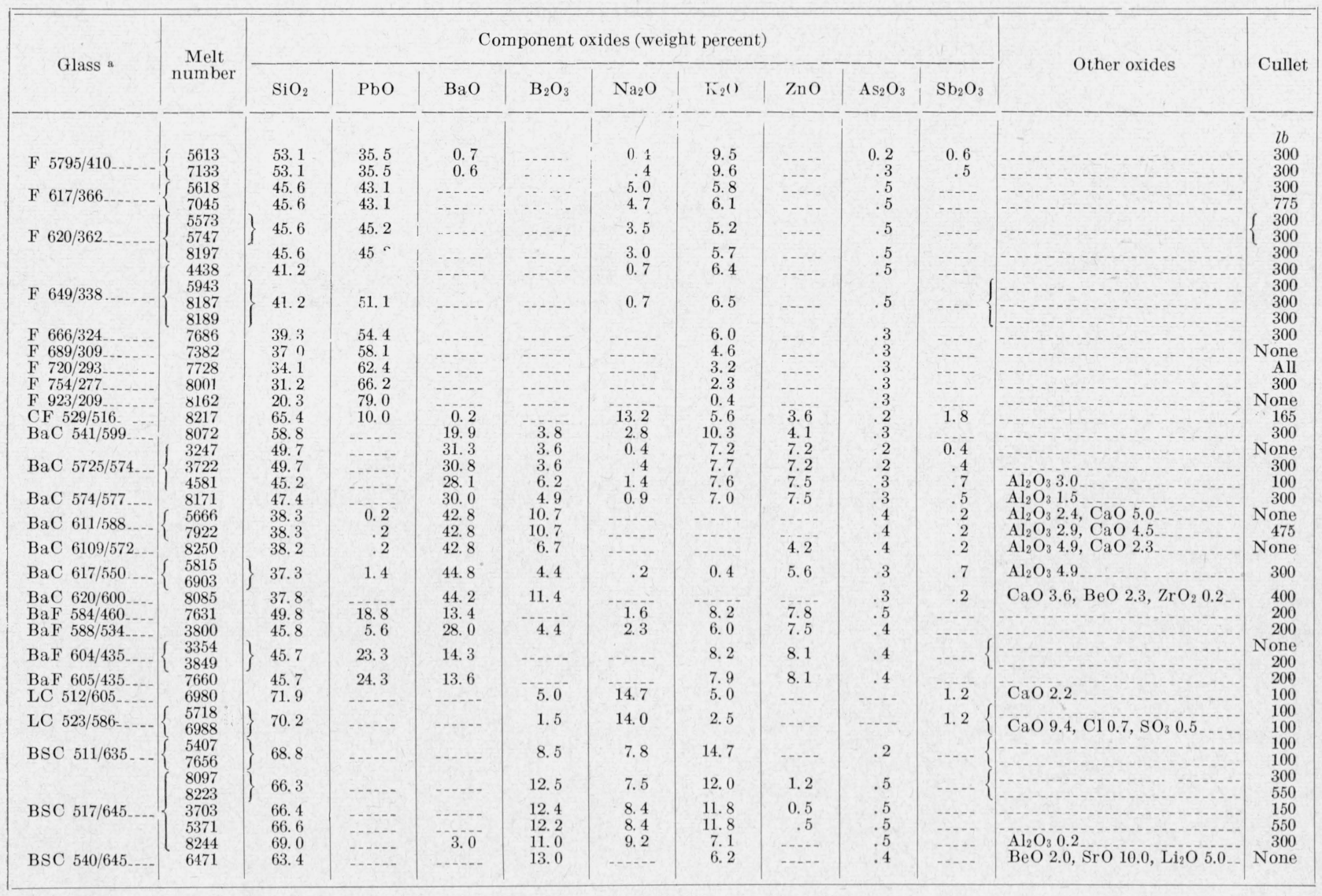

a $\mathrm{F}=$ flint, $\mathrm{BaC}=$ barium crown, $\mathrm{LC}=$ light crown, $\mathrm{BaF}=$ barium flint, $\mathrm{BSC}=$ borosilicate crown, $\mathrm{CF}=$ crown flint.

ical balance. Upward or downward motion of the ball in the liquid is produced by changing the weights on the right-hand pan of the balance. The velocity of the ball is indicated by the motion of the balance pointer, which is observed through a Brinell microscope. The sample of glass is in the cylindrical platinum viscosity crucible $(2 \mathrm{in}$. in diameter and 3 in. high).

The furnace (fig. 1 ) is supported on an adjustable stand by means of which it can be moved vertically. Over the ends of the main platinum alloy resistance winding there are two smaller separately controlled auxiliary windings to control vertical thermal gradients. Temperatures are measured by means of three thermocouples (Pt vs $\mathrm{Pt}-10$ percent $\mathrm{Rh}$ ), which can be pushed into contact with the crucible, which contains the molten glass. Another thermocouple placed near the center of the crucible is connected to a potentiometer-type controller, by means of which the temperature is held constant during a determination. The power to the furnace is supplied through a $3 \mathrm{KVA}$ constant voltage transformer. A water-cooled copper shield protects the ba a sce from the heat of the furnace.

The apparatus was calibrated with a liquid of known viscosity.

\section{(b) Measurement of Viscosity of Calibrating Liquid}

Preliminary studies of the method and calibrations of the apparatus were made with NBS Standard Oil $\mathrm{P}$ used for calibrating viscometers. As the viscosity values available did not cover so large a range as was desired, additional viscosity values at other temperatures were obtained with a freely falling sphere apparatus.

Figure 2 is a diagrammatic sketch of this apparatus. It consists of two concentric glass tubes, each about 24 in. long with liquid from a thermostatically controlled bath circulated through the annular space between them. A thermometer inserted through a hole in the upper rubber spacer measures the temperature of the thermostatically controlled liquid. The central tube is a $100-\mathrm{ml}$ burette with the stopcock portion removed and is closed at both ends by rubber stoppers. A short piece of $6-\mathrm{mm}$ glass tubing with a piece of rubber tubing over the lower end projects through a hole in the upper stopper. This piece of rubber tubing is of small bore and sufficiently flexible to hold different sizes of ball bearings above the test liquids until they are released by pushing down on a glass rod inside the glass tubing. 


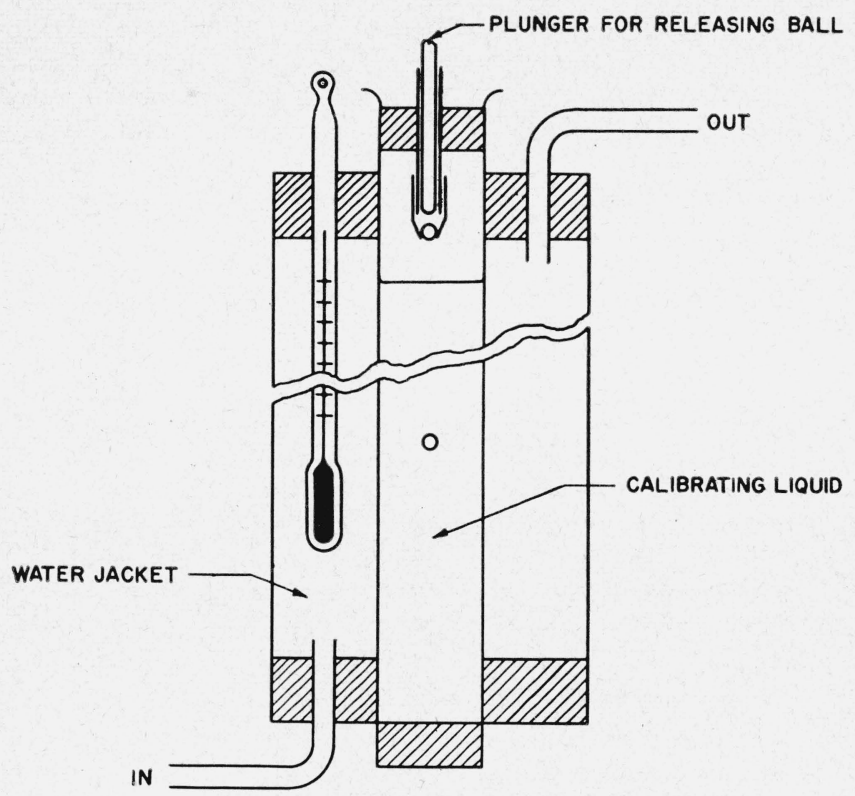

Figure 2. Freely falling sphere apparatus.

The inside diameter of the burette was measured at several places by means of a cathetometer microscope while the burette was immersed in a liquid of index 1.51 contained in a glass vessel with plane parallel walls. The average of nine such measurements was $1.489 \mathrm{~cm}$ with a standard deviation of 0.3 percent. The distance between even numbered milliliter marks on the burette was likewise measured at many different places. The average obtained for 21 measurements was $0.5831 \mathrm{~cm} / \mathrm{ml}$ with a standard deviation of 0.3 percent.

The spheres used were ball bearings, some of steel and some of brass. Each one was measured with a micrometer to approximately $0.0001 \mathrm{in}$. and weighed to $0.1 \mathrm{mg}$ on an analytical balance. Most of the balls were $1 / 8,3 / 16$, and $1 / 4$ in. in diameter. A few measurements were made with $5 / 16^{-}$and $3 / 8^{-i n}$. balls.

Each ball was held in the holder above the liquid for a length of time considered sufficient to allow it to reach the temperature of the test liquid. Velocities were measured after the ball had traveled a considerable distance through the liquid, usually $6 \mathrm{~cm}$ or more.

For the calculation of viscosity the usual form of Stokes law was modified as follows:

where

$$
F=\left(W-1 / 6 \pi d^{3} \rho\right) g,
$$

$F=$ driving force

$W=$ weight of the sphere in grams

$d=$ diameter of sphere in centimeters

$\rho=$ density of the test liquid in grams per cubic centimeter

$g=$ gravitational constant, 980 dynes $/ \mathrm{cm}$.
When constant velocity is reached, the resisting force, according to Stokes, is

$$
R=3 \pi \eta_{s} d v,
$$

where

$R=$ resisting force

$\eta_{s}=$ viscosity in poises, according to Stokes

$v=$ velocity in centimeters per second.

At equilibrium, $F=R$ from which it can be shown that

$$
\eta_{s}=\frac{\left(w-1 / 6 \pi d^{3} \rho\right) g}{3 \pi d v}=\frac{\left(W-1 / 6 \pi d^{3} \rho\right) g t}{3 \pi d(0.5831 N)}
$$

where

$t=$ time in seconds

$N=$ number of milliliter divisions traversed in time, $t$.

As Stokes law is accurate only for a sphere in a medium of infinitely large extent, a correction for the boundary conditions is necessary. Several such correction formulas have been proposed and used. In this study it was considered desirable to compare the Faxen $[1]^{2}$ correction with the one proposed by Francis [2]. The Faxen correction is

$$
F_{a}=1-2.104 d / D+2.09\left(\frac{d}{D}\right)^{3}-0.95\left(\frac{d}{D}\right)^{5},
$$

where

$d=$ diameter of sphere

$D=$ diameter of test vessel.

The Francis correction $F_{r}$ is given by the equation

$$
F_{r}=\left(1-\frac{d}{D}\right)^{2.25}
$$

After each correction was calculated it was multiplied by the value obtained from Stokes law. Thus

$$
\begin{aligned}
& \eta_{F_{a}}=\eta_{s} F_{a}, \\
& \eta_{F_{r}}=\eta_{s} F_{r} .
\end{aligned}
$$

Table 2 gives the results obtained. To compare the two corrections, the data have been classified into groups of approximately equal temperature, although there was some temperature drift during a set of determinations. The densities of the test liquid were measured by the Engine and Lubrication Section of this Bureau with a picnometer method.

2 Figures in brackets indicate the literature references at the end of this paper. 
TABLE 2. Comparison of viscosity correction formulas

\begin{tabular}{|c|c|c|c|c|c|c|c|}
\hline \multirow{2}{*}{ Temperature } & \multirow{2}{*}{$\begin{array}{l}\text { Ball } \\
\text { diam- } \\
\text { eter, } d\end{array}$} & \multirow{2}{*}{ Weight } & \multirow{2}{*}{$\begin{array}{l}\text { Num- } \\
\text { ber of } \\
\text { divi- } \\
\text { sions }\end{array}$} & \multirow{2}{*}{ Time } & \multicolumn{3}{|c|}{ Viscosity by- } \\
\hline & & & & & $\begin{array}{c}\text { Stokes, } \\
\eta_{s}\end{array}$ & $\begin{array}{c}\text { Faxen, } \\
\eta_{F a}\end{array}$ & $\begin{array}{c}\text { Francis, } \\
\eta_{F_{T}}\end{array}$ \\
\hline $\begin{array}{l}{ }^{\circ} \mathrm{C} \\
33.40 \\
33.40 \\
33.36 \\
33.34 \\
33.31\end{array}$ & $\begin{array}{c}c m \\
0.3183 \\
.4755 \\
.6345 \\
.4755 \\
.3190\end{array}$ & $\begin{array}{l}g \\
0.1323 \\
.4394 \\
1.0430 \\
.4389 \\
.1330\end{array}$ & $\begin{array}{l}70 \\
70 \\
70 \\
70 \\
70\end{array}$ & $\begin{array}{l}\text { sec } \\
613.8 \\
402.8 \\
354.8 \\
399.8 \\
616.4\end{array}$ & $\begin{array}{r}\text { Poises } \\
576 \\
840 \\
1,316 \\
833 \\
580\end{array}$ & $\begin{array}{c}\text { Poises } \\
328 \\
330 \\
331 \\
327 \\
330\end{array}$ & $\begin{array}{c}\text { Poises } \\
335 \\
354 \\
377 \\
351 \\
337\end{array}$ \\
\hline $\begin{array}{l}\text { Avg__33. } 36 \\
\text { Standard de- } \\
\text { viations...- } \\
\text { Capillary } \\
\text { flow_- }\end{array}$ & $\cdots$ & $-\cdots$ & $\begin{array}{l}\cdots \\
\cdots \\
\cdots\end{array}$ & -... & - & $\begin{array}{r}329 \\
1.5 \\
328\end{array}$ & $\begin{array}{r}351 \\
15.1 \\
-\end{array}$ \\
\hline $\begin{array}{l}29.63 \\
29.60 \\
29.60 \\
29.55 \\
29.50 \\
29.45 \\
29.42 \\
29.38 \\
29.40\end{array}$ & $\begin{array}{l}.6345 \\
.6345 \\
.4755 \\
.3170 \\
.6365 \\
.6345 \\
.4755 \\
.3185 \\
.4750\end{array}$ & $\begin{array}{r}1.0430 \\
1.0430 \\
.4394 \\
.1305 \\
1.1873 \\
1.0430 \\
.4395 \\
.1326 \\
.4900\end{array}$ & $\begin{array}{l}52 \\
52 \\
70 \\
72 \\
70 \\
70 \\
72 \\
72 \\
70\end{array}$ & $\begin{array}{l}370.8 \\
367.8 \\
546.6 \\
865.7 \\
422.9 \\
490.4 \\
570.6 \\
880.3 \\
489.7\end{array}$ & $\begin{array}{r}1,719 \\
1,705 \\
1,140 \\
782 \\
1,806 \\
1,819 \\
1,157 \\
804 \\
1,158\end{array}$ & $\begin{array}{l}433 \\
429 \\
448 \\
447 \\
452 \\
458 \\
455 \\
458 \\
456\end{array}$ & $\begin{array}{l}493 \\
489 \\
480 \\
456 \\
515 \\
522 \\
487 \\
468 \\
488\end{array}$ \\
\hline $\begin{array}{l}\text { Avg } 29.50 \\
\text { Standard } \\
\text { deviations } \\
\text { Capillary } \\
\text { flow }\end{array}$ & $\cdots$ & $\cdots$ & $\begin{array}{l}--\cdot \\
-\cdots-\end{array}$ & -.... & -... & $\begin{array}{c}448 \\
10.1 \\
442\end{array}$ & $\begin{array}{r}489 \\
19.4 \\
----\end{array}$ \\
\hline $\begin{array}{l}26.61 \\
26.58 \\
26.71 \\
26.83 \\
26.90 \\
27.18 \\
27.27 \\
27.35 \\
27.40\end{array}$ & $\begin{array}{r}0.3167 \\
.3162 \\
.3162 \\
.4752 \\
.6345 \\
.3162 \\
.3180 \\
.4752 \\
.6345\end{array}$ & $\begin{array}{r}0.1305 \\
.1302 \\
.1303 \\
.4386 \\
1.0430 \\
.1298 \\
.1319 \\
.4388 \\
1.0430\end{array}$ & $\begin{array}{l}72 \\
72 \\
66 \\
76 \\
70 \\
70 \\
70 \\
70 \\
70\end{array}$ & $\begin{array}{r}1,114.8 \\
1,112.8 \\
1041.8 \\
764.2 \\
629.0 \\
1,049.0 \\
1,035.0 \\
678.5 \\
582.4\end{array}$ & $\begin{array}{r}1,009 \\
1,007 \\
1,029 \\
1,466 \\
2,333 \\
973 \\
969 \\
1,414 \\
2,160\end{array}$ & $\begin{array}{l}577 \\
577 \\
589 \\
577 \\
587 \\
557 \\
553 \\
556 \\
544\end{array}$ & $\begin{array}{l}589 \\
588 \\
601 \\
617 \\
669 \\
569 \\
564 \\
596 \\
619\end{array}$ \\
\hline $\begin{array}{l}\text { Avg } 26.98 \\
\text { Standard de- } \\
\text { viations } \\
\text { Capillary } \\
\text { flow }\end{array}$ & -.. & - & $\cdots$ & -... & ... & $\begin{array}{r}569 \\
15 \\
570\end{array}$ & $\begin{array}{r}601 \\
30\end{array}$ \\
\hline $\begin{array}{l}11.95 \\
11.95 \\
11.99 \\
11.95 \\
12.00 \\
12.06\end{array}$ & $\begin{array}{r}0.3167 \\
.4755 \\
.6345 \\
.4742 \\
.7916 \\
.9515\end{array}$ & $\begin{array}{l}0.1300 \\
.4390 \\
1.0430 \\
.4925 \\
\text { 2. } 0196 \\
3.4812\end{array}$ & $\begin{array}{l}67 \\
68 \\
80 \\
78 \\
70 \\
66\end{array}$ & $\begin{array}{l}4,356.2 \\
2,831.4 \\
2,807.4 \\
2,867.0 \\
2,727.2 \\
3,105.4\end{array}$ & $\begin{array}{r}4,214 \\
6,073 \\
9,110 \\
6,119 \\
15,695 \\
27,110\end{array}$ & $\begin{array}{l}2,411 \\
2,387 \\
2,294 \\
2,413 \\
2,436 \\
2,695\end{array}$ & $\begin{array}{l}2,460 \\
2,556 \\
2,612 \\
2,582 \\
2,849 \\
2,726\end{array}$ \\
\hline $\begin{array}{l}\text { Avg } 11.98 \\
\text { Standard de- } \\
\text { viations... }\end{array}$ & -.. & -... & & -.... & -... & $\begin{array}{r}2,439 \\
123\end{array}$ & $\begin{array}{r}2,631 \\
125\end{array}$ \\
\hline $\begin{array}{l}19.20 \\
19.06 \\
19.06 \\
19.06 \\
19.12\end{array}$ & $\begin{array}{r}0.3175 \\
.4755 \\
.6345 \\
.7915 \\
.3167\end{array}$ & $\begin{array}{r}0.1324 \\
.4394 \\
\text { 1. } 0430 \\
\text { 2. } 0186 \\
.1308\end{array}$ & $\begin{array}{l}88 \\
76 \\
76 \\
70 \\
68\end{array}$ & $\begin{array}{l}2,772.8 \\
1,558.6 \\
1,338.8 \\
1,412.6 \\
2,164.5\end{array}$ & $\begin{array}{l}2,079 \\
2,994 \\
4,573 \\
8,125 \\
2,079\end{array}$ & $\begin{array}{l}1,188 \\
1,177 \\
1,151 \\
1,261 \\
1,189\end{array}$ & $\begin{array}{l}1,212 \\
1,260 \\
1,311 \\
1,474 \\
1,214\end{array}$ \\
\hline $\begin{array}{l}\text { Avg_-19.10 } \\
\text { Standard de- } \\
\text { viations. }\end{array}$ & $\ldots$ & -... & 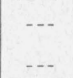 & - & $+\cdots$ & $\begin{array}{r}1,193 \\
37\end{array}$ & $\begin{array}{r}1,294 \\
116\end{array}$ \\
\hline $\begin{array}{l}11.78 \\
11.80 \\
11.82 \\
11.82 \\
11.82 \\
11.82\end{array}$ & $\begin{array}{r}0.6345 \\
.7920 \\
.6363 \\
.4755 \\
.4755 \\
.3177\end{array}$ & $\begin{array}{r}\text { 1. } 0430 \\
\text { 2. } 0188 \\
\text { 1. } 1834 \\
.4394 \\
.4940 \\
.1493\end{array}$ & $\begin{array}{l}70 \\
72 \\
70 \\
70 \\
74 \\
70\end{array}$ & $\begin{array}{l}2,679.5 \\
3,069.1 \\
2,274.6 \\
2,996.3 \\
2,790.4 \\
4,044.1\end{array}$ & $\begin{array}{r}9,937 \\
17,149 \\
9,681 \\
6,248 \\
6,276 \\
4,355\end{array}$ & $\begin{array}{l}2,502 \\
2,656 \\
2,425 \\
2,456 \\
2,467 \\
2,486\end{array}$ & $\begin{array}{l}2,849 \\
3,107 \\
2,762 \\
2,630 \\
2,642 \\
2,538\end{array}$ \\
\hline $\begin{array}{c}\text { Avg_11. } 81 \\
\text { Standard de- } \\
\text { viations... }\end{array}$ & -.. & -... & & - & -..- & $\begin{array}{r}2,499 \\
74\end{array}$ & $\begin{array}{r}2,755 \\
176\end{array}$ \\
\hline
\end{tabular}

Inspection of the data in table 2 shows that the viscosities calculated with the Faxen correction are on the average lower than those obtained, using the Francis correction. The reproducibility of the Faxen results is better, as judged by the size of the standard deviations. Viscosity data supplied by the Engine and Lubrication Section, using a capillary flow method, are in better agreement with the Faxen results than with the Francis values. The Francis values have a distinct tendency to become larger as the ball size increases. For these reasons, only the results obtained with the Faxen correction received any further consideration.

An equation was fitted by the method of least squares to the Faxen data shown in table 2, as well as to other data obtained with the freely falling sphere method at lower temperatures and with the capillary flow results at temperatures between $30^{\circ}$ and $60^{\circ} \mathrm{C}$. The equation took the following form [3]

$L=218.98+1.3914(t-30)+0.00163(t-30)^{2}$,

where

$$
\begin{aligned}
t & ={ }^{\circ} \mathrm{C} \\
L & =1301 / \log 2000 \eta .
\end{aligned}
$$

\section{(c) Calibration}

In making calibrations, the furnace as replaced by a thermostatically controlled bath, and the cylindrical platinum viscosity crucible was placed in a liquid-tight brass container (fig. 3).

When the apparatus reached the desired temperatures, weights were placed on the right-hand pan of the balance, and the time required for the balance pointer to move a selected number of scale divisions was measured with a stop watch. At low viscosities where the velocity was high, a large test distance was selected in order to get as accurate a time measurement as possible. Furthermore, at low viscosities the balance pointer was brought a considerable distance away from the region where the velocity was to be measured, in order to allow the sphere to reach an equilibrium velocity before approaching the test distance. At high viscosities where the velocity of

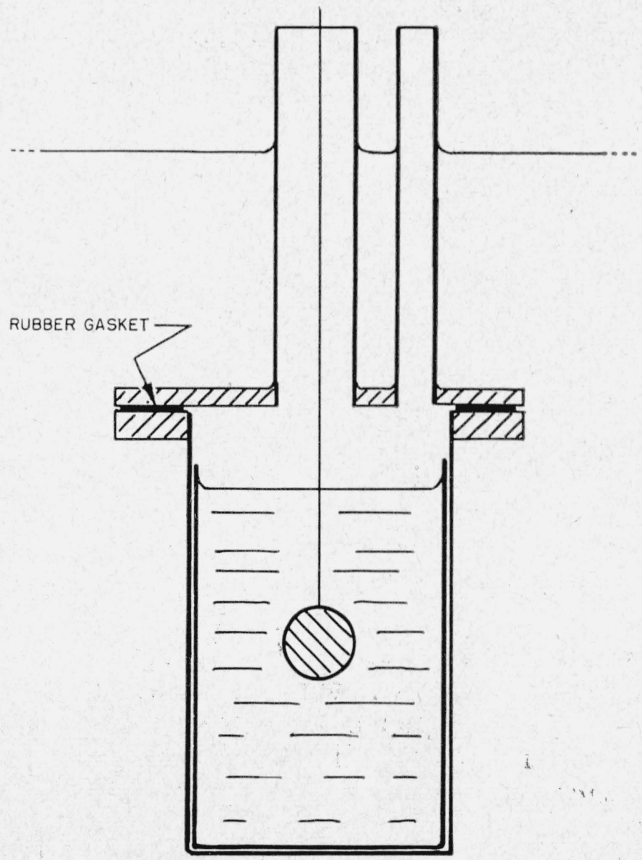

FIGURE 3. Liquid-tight container for use in calibrations. 


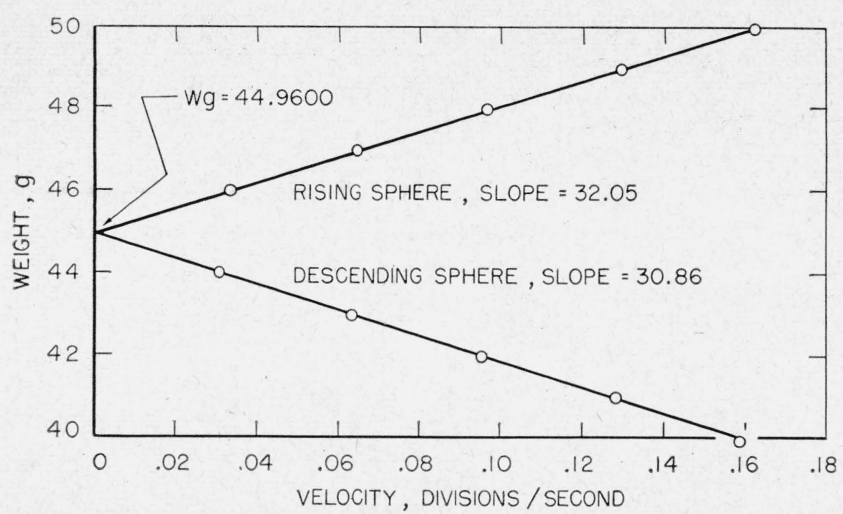

Figure 4. Effect of weight on velocity of counterbalanced platinum sphere in calibrating liquid at $-7.88^{\circ} \mathrm{C}$.

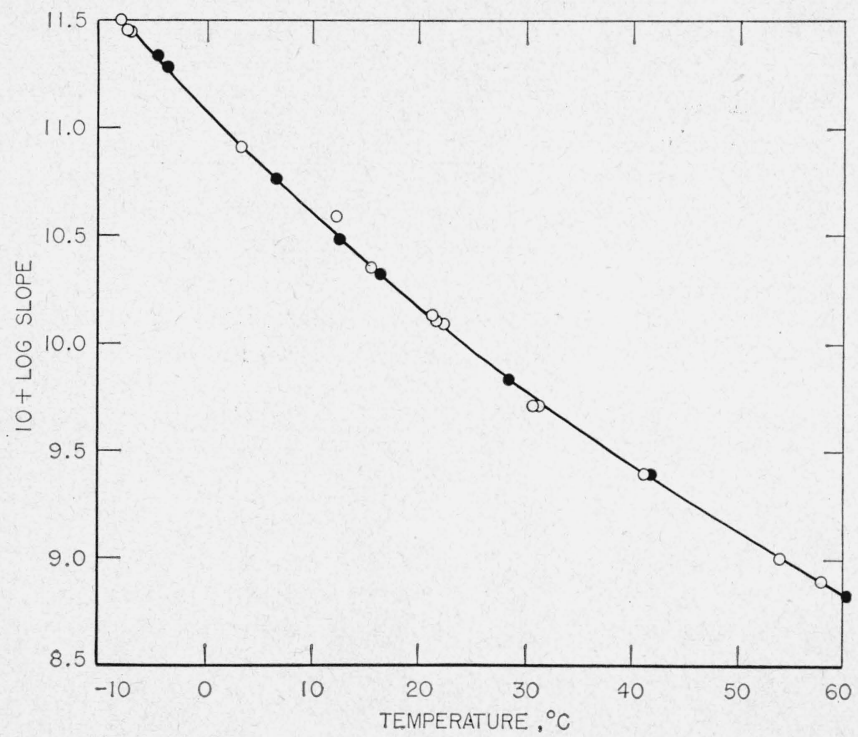

Figure 5. Logarithm of the average slopes of the weightversus-velocity curves of a series of calibrations plotted against the Centigrade temperature.

Open circles represent old data, whereas filled circles represent the latest data.

the sphere was low the selected test distance was small, and the starting position of the pointer was closer to the measuring region in order to save time. In all cases, however, the zero of the balance scale divided the test distance into halves. The weights were selected to give a range of velocities in both directions.

Figure 4 shows in graphical form the effect of different weights of the sphere. At weights greater than the weight of the sphere in the test liquid the motion is upward, at lower weights the motion is downward. The load versus velocity curve is a straight line. The slope of the rising line is usually greater than that of the descending line. The difference in the slopes of the two curves is attributed to the influence of the liquid adhering to the wire. In practice the average slope was used in making calculations.

The effect of temperature on the slope of the loadvelocity curves was determined over the temperature range -5 to $+60^{\circ} \mathrm{C}$. Figure 5 shows a plot of the results obtained. The filled circles represent the latest data, whereas the circles represent the data obtained in a similar series of experiments about a year before. The agreement indicates that the results were not significantly affected by the wear to which the crucible and sphere were subjected during the course of many measurements made during that year.

Previous experience had shown that a plot of log viscosity versus log slope could be represented by a straight line. Figure 6 shows a plot of data from a previous set of calibrations to illustrate this point. A straight line fitted by the method of least squares to the data obtained in the last set of calibrations gave the following equation

$$
\log \eta=1.0266(10+\log S)-7.4070,
$$

upon which all the viscosity results reported in this study are based. $S$ is the slope of the load versus velocity curve.

If it is assumed that $\eta=K S$, where $K$ is an instrumental constant and $K$ is solved for, it will be noted that $K$ is not constant but increases with viscosity. The probability is that the friction and inertia of the balance is at least partially responsible for the increase of $K$ with viscosity. Part of the applied force is needed to move the balance; therefore, the sphere moves more slowly than if the whole force were acting on it. This effect results in a steeper slope than would otherwise be the case and $K$ must be correspondingly smaller. As the retarding effect is a larger fraction of the total force at low viscosities, where low loads are used, the constant is smaller at low viscosities. The increase of calibration constant

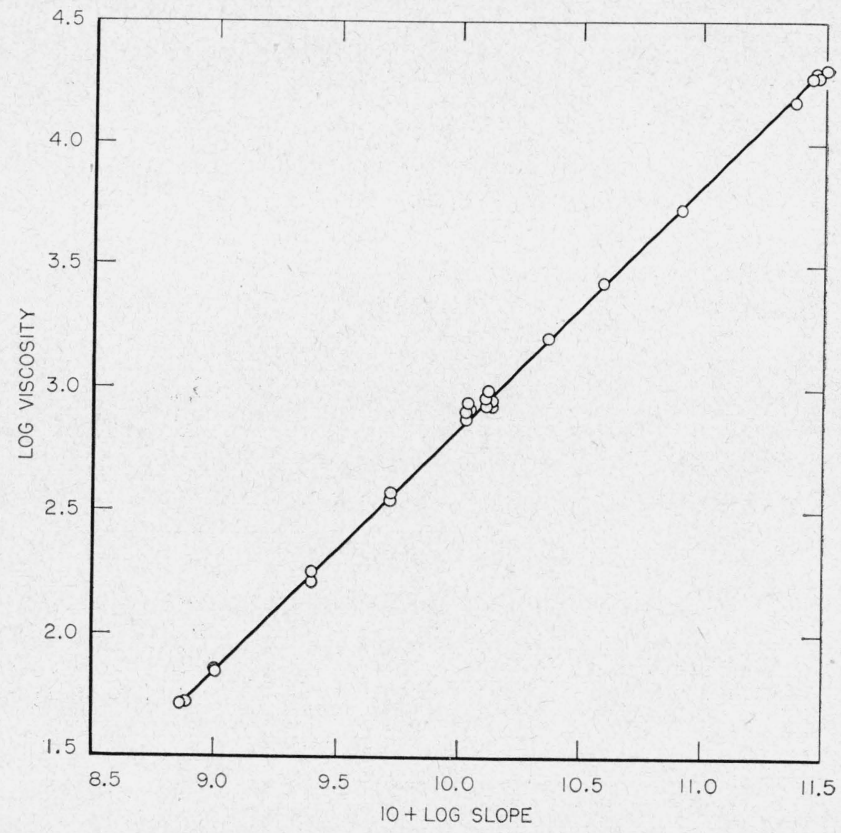

Figure 6. Logarithm of the viscosity of the calibrating liquid plotted against the logarithm of the average slopes of the weightversus-velocity curves of a series of calibrations. 
was noted by other workers using the restrained falling sphere method, one of whom [4] investigated the possibility that his glass was showing nonNewtonian behavior.

Additional evidence that friction and inertia are the causes of the change in $K$ with increasing viscosity is to be found in the experience of investigators who worked with large balances [5]. These workers used balances with long beams in order to minimize side motion of the sphere. Their results show a larger change of $K$ with viscosity than was found in the present study.

It is interesting to calculate the value of $K$ by assuming Stokes law and the Faxen correction to apply. This calculation neglects the effect of the small platinum ring that is welded to the sphere, and to that part of the supporting wire that is immersed in the test liquid. As the neglected portions introduce a viscous traction that is not considered, the calculated $K$ should be higher than the observed one.

Thus according to Faxen's modification of Stokes law

$$
\eta=\eta_{s} F_{a}=\frac{\left(W-W_{g}\right) g F_{a}}{3 \pi d V_{c}}
$$

where

$W=$ weight of sphere in air

$W_{g}=$ weight of sphere in test liquid

$V_{c}=$ velocity in centimeters per second.

As

$$
S=\frac{W-W_{g}}{V_{n}}
$$

where

$V_{n}=$ velocity in balance divisions per sec, and $K=\eta / S$,

$$
K=\frac{g F_{a} V_{n}}{3 \pi d V_{c}}
$$

By measurement with a cathetometer microscope it was found that the movement of the balance pointer across six scale divisions was equal to a vertical travel of the ball of $2.3 \mathrm{~mm}$. Thus $V_{N}=26.09 V_{c}$, and

$$
K=\frac{26.09 g F_{a}}{3 \pi d}
$$

The inside diameter of the viscosity crucible was 5.2 $\mathrm{cm}$ and the diameter of the sphere $(d) 1.5 \mathrm{~cm}$. Thus $d / D=0.288, F_{a}=0.4586$, and $g=980$.

These values substituted in eq 10 yield a value of 825. The observed constant as computed from eq 7 varied from about 670 to about 800 over the range of viscosities measured during the calibrations.

\section{(d) Procedure With Glasses}

The test glasses were moulded into solid cylinders designed to fill the crucible with molten glass to a depth of 3 in. The moulded glass blank was placed in the platinum crucible and slowly heated to about $500^{\circ} \mathrm{C}$ in an electrically heated laboratory muffle furnace. Then it was quickly transferred to the viscosity furnace, which was previously heated to about $1,300^{\circ} \mathrm{C}$. The ball was then lowered to a position above the molten glass. The furnace was raised slowly by means of the adjustable stand until the bottom of the sphere touched the molten glass. This position could be readily observed by first imparting to the ball a pendulum-like motion, which was quickly damped when the ball touched the surface of the viscous glass melt. The furnace was then raised $1.5 \mathrm{in}$. to allow sufficient immersion for the sphere.

Measurements of load versus velocity were made at 100-deg C intervals, decreasing the temperature until the glass was too viscous to allow the ball to move under reasonable loads and convenient times. Each time the temperature of the furnace was decreased $100 \mathrm{deg} \mathrm{C}$, the furnace was raised $0.74 \mathrm{~mm}$ to compensate for the change in the relative position of the sphere caused by shrinkages of the furnace, the glass in the crucible, and the supporting platinum wire. The change in the level of the glass in the crucible was measured in a separate experiment by means of a platinum contact rod mounted on a scale outside the furnace.

\section{Rotational Viscometer Method}

Prior to work with the sphere method, some viscosity measurements were made with a small rotation viscometer that has already been described in the literature [6]. This apparatus was limited to measurements below $1,100^{\circ} \mathrm{C}$.

\section{Measurement of Density}

\section{Sphere Method}

By extrapolating the load-velocity lines (fig. 4) back to zero velocity, $W_{g}$, the weight of the sphere in the test liquid can be obtained. The average of the two values obtained was used. In general, after the load-velocity points were plotted straight lines were drawn by inspection. Two well-fitting points, covering as large an interval of load as the data permitted, were selected from each line. Calculations of $S$ and $W_{g}$ were made from the selected points as follows: Let $W_{1}$ and $W_{2}$ be the weights at the two selected points and $V_{1}$ and $V_{2}$ be the corresponding velocities.

Then

from which

$$
S=\frac{W_{2}-W_{g}}{V_{2}}=\frac{W_{1}-W_{g}}{V_{1}},
$$

$$
W_{g}=\frac{W_{1} V_{2}-W_{2} V_{1}}{V_{2}-V_{1}} .
$$

The density corrected for the effect of surface tension on the suspending wire was computed from the following equation

$$
\rho=\frac{W-\left(W_{g}-0.46 \pi d \sigma / g\right)}{V_{0}(1+3 \alpha t)}
$$


where

$\rho=$ density of the liquid in grams per cubic centimeter,

$W=$ weight of platinum sphere plus that portion of the suspending wire immersed in the test liquid,

$d=$ diameter of suspending wire in centimeters,

$\sigma=$ surface tension of the test liquid (known from previous work [7]),

$\alpha=$ linear thermal expansion of platinum,

$V_{0}=$ volume of sphere at room temperature,

$0.46=$ Wilhelmy correction for the effect of surface tension on thin wires, [8] and

$t=$ temperature in $\operatorname{deg} \mathrm{C}$.

The volume of the sphere plus that portion of the suspending wire immersed in the test liquid was determined by measuring the buoyant effect of distilled water,

$$
V_{0}=\frac{W-\left(W_{g}-\frac{0.46 \pi d \sigma_{0}}{g}\right)}{\rho_{0}}
$$

where $\rho_{0}$ is the density of distilled water at the temperature at which $\dot{V}_{0}$ was determined.

\section{The Volumeter Method}

(a) Principle of Method

Early in 1943 a project to measure the density of optical glasses at high temperatures with a volumeter method was initiated by B. Fonoroff. This method enables the calculation of the volume of a given weight of glass by determining the position of the surface of a melt in a calibrated crucible. The position of the surface is obtained by locating the top of the crucible with reference to a scale outside the furnace, finding the position of the glass surface on the same scale and taking the difference as a measure of the volume. This method avoids errors due to expansion of the furnace and the crucible supports. Thermal expansion of that part of the crucible above the glass level is compensated by making the measurements with a rod of the same material as the crucible and in thermal equilibrium with it.

\section{(b) Apparatus}

A diagram of the apparatus is shown in figure 7 . The furnace was wound with three separate coils of platinum alloy resistance wire. A uniform temperature throughout a large portion of the furnace could be obtained by adjusting the current in each coil. Three noble-metal thermocouples (indicated by crosses in fig. 7) were used to measure the temperature.

The long-necked platinum crucible (shaped like a volumetric flask) has a flat horizontal lip at the mouth. The crucible could be raised while in the furnace by means of a sillimanite tube (not shown in fig. 7), which extended downward through a hole in the center of the furnace floor.

The depth gage consisted of an upright steel rod square in cross section and graduated in millimeters,

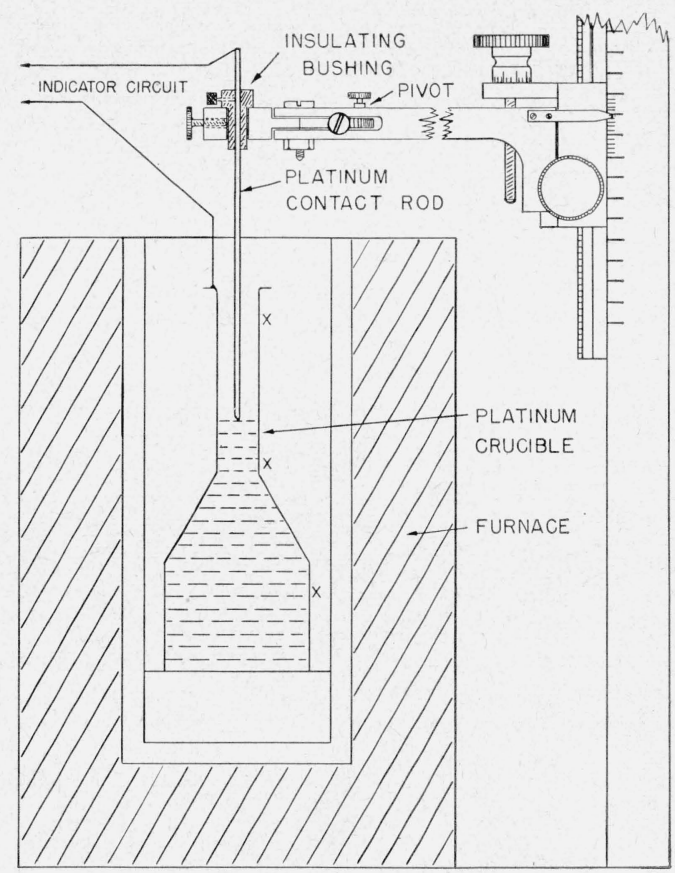

Figure 7. Volumeter apparatus.

Small crosses mark location of thermocouples.

and a movable arm that supported a rod of the same material as the volumeter. The contact could be turned through a small horizontal arc by means of a pivot located near the end of the movable arm. This enabled one to set the rod over the lip of the crucible or over its center without moving the crucible or the depth gage. The arm could be moved vertically by means of a rack and pinion arrangement. Fine adjustments of the position of the arm were made with a micrometer screw. The head of the screw was graduated into 50 divisions, and, as two revolutions of the screw corresponded to a vertical motion of $1 \mathrm{~mm}$, the smallest measurable motion was $0.01 \mathrm{~mm}$. The rod and crucible were connected in series with a neon glowlamp and a source of current, so that the appearance of a light indicated contact.

\section{(c) Calibration}

Before each determination of the expansion of a glass sample the volumeter was calibrated at room temperature. The crucible was filled to within $1 \mathrm{~cm}$ of the top with a dilute electrolyte solution of known density and then weighed. The position of the surface of the liquid was determined with the depth gage. The movable arm was then raised and contact made with the lip of the crucible. The distance between the liquid surface and the lip corresponded to a definite volume at room temperature. About $1 \mathrm{ml}$ of solution was removed with a pipette, the position of the liquid surface with respect to the lip redetermined, and the volumeter reweighed. These operations were repeated until the level of the solution was at the base of the neck of the crucible. From the known density of the weights of the solution, the 
volumes corresponding to the various depths of the liquid surface were calculated. As the neck of the crucible was found to be very uniform in diameter, a calibration chart was made that showed volume of the liquid corresponding to any depth in the crucible.

\section{(d) Procedure}

Samples of optically homogeneous glass were crushed to conveniently sized pieces in a steel mortar. A magnet was passed over the glass to remove magnetic particles and the sample was then washed and dried.

The crucible, filled with the crushed glass, was weighed and lowered into the furnace, which had previously been heated to $1,400^{\circ} \mathrm{C}$. When the glass had melted the crucible was raised until the lip was just below the top of the furnace, and additional portions of glass were cautiously added from a weighing bottle by means of a platinum spatula. Several such additions were made until the glass level was a few centimeters from the top of the crucible. The melt was then stirred with a platinum wire to remove bubbles. The amount of glass removed by this process was determined by weighing the rod before and after stirring.

The temperature was lowered at a rate of $50^{\circ} \mathrm{C} /$ hour, depth readings being made at half-hour intervals. As the lip measurement changed relatively little with temperature, the measuring rod was kept just above it most of the time and frequent readings were taken. When the time approached for ascertaining the depth of the glass, the rod was swiveled into position over the center of the crucible and lowered to a position very close to the surface of the glass. Temperature readings were then made, contact made with the glass, and the temperature again measured. Then the rod was raised, swiveled over the lip, about 2 minutes allowed for temperature equilibrium, and the height of the lip ascertained again. The two lip readings were averaged, as were the temperature readings.

Measurements were made during continuous cooling until such low temperatures were reached (approximately $700^{\circ} \mathrm{C}$ ) that consistent measurements were not obtained. The temperature was then raised in 25-deg steps, holding at each step until concordant depth readings were obtained.

The volume corresponding to a given depth was read from the calibration chart. This was the volume at the temperature of calibration and was adjusted to the temperature of test by the use of the following formula

where

$$
V_{t}=V_{0}\left(1+\alpha t+\beta t^{2}\right)
$$

$$
\begin{aligned}
& V_{t}=\text { volume at temperature } t^{\circ} \mathrm{C}, \\
& V_{0}=\text { volume at } 0^{\circ} \mathrm{C} \\
& \alpha=2.4 \times 10^{-5} \\
& \beta=6.0 \times 10^{-9}
\end{aligned}
$$

${ }_{3}$ The constants $\alpha$ and $\beta$ were calculated from linear expansion data obtained from the Thermal Expansion Section of this Bureau.

\section{Viscosity Results}

\section{Sphere Viscometer Data}

The viscosities obtained with the restrained sphere method are given in table 3 . In the glass industry it is common practice to compare viscosities in terms of the temperature required to attain a given viscosity. Table 4 presents the experimental results in this form. Smooth curves were drawn through the points representing log viscosity versus temperature attained in each determination. The temperatures corresponding to the selected viscosities were then estimated from this curve. A comparison of reproducibility in terms of temperature at a given viscosity is thus made available in table 4. Beneath each average is the result obtained by estimation from a smooth curve drawn through all the data on that glass when more than one set of observations was available. The two sets of curves and the estimates derived from them were prepared by different investigators.

TABLE 3. Viscosity of optical glasses-sphere method

$\mathrm{F}=$ flint $; \mathrm{BaC}=$ barium crown; $\mathrm{LC}=$ light crown; $\mathrm{BaF}=$ barium flint; $\mathrm{BSC}=$ borosilicate crown; $\mathrm{BF}=$ crown flint

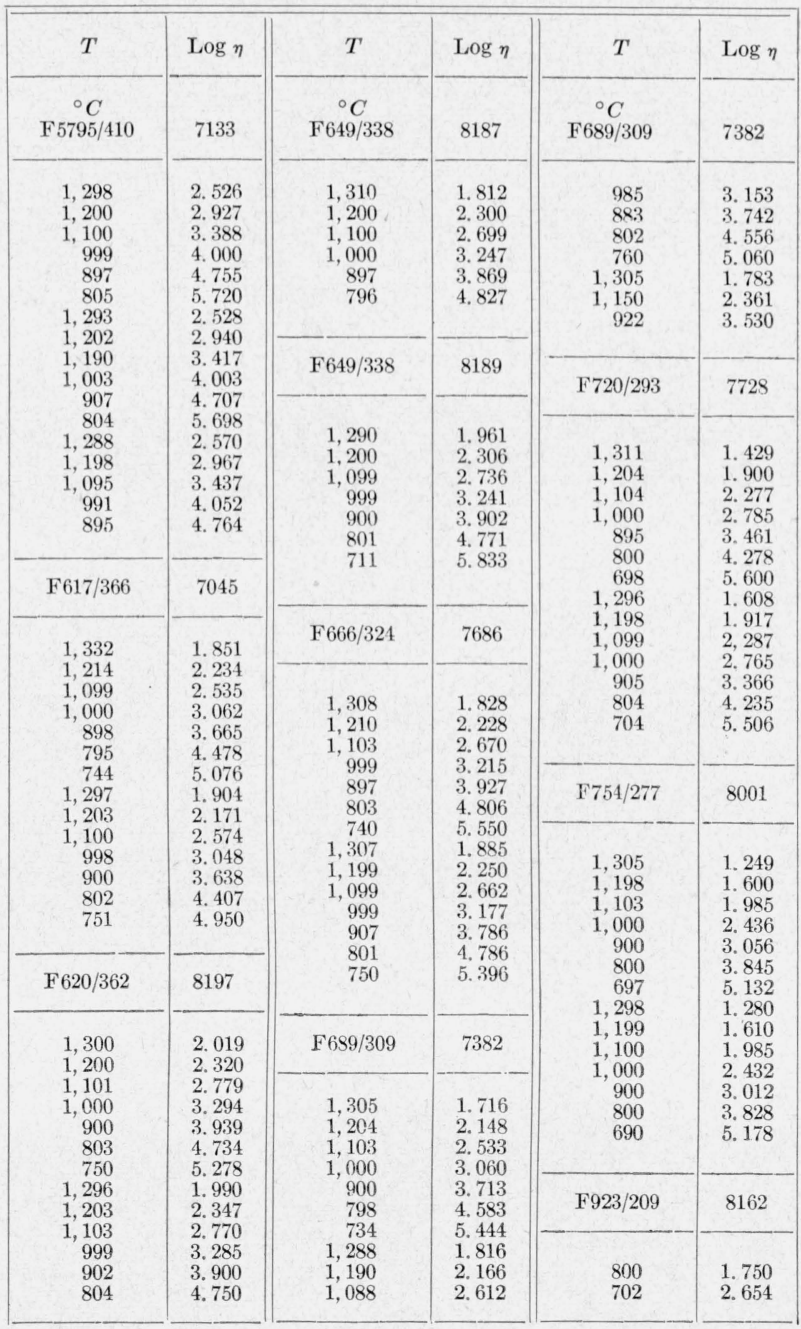


TABLE 3.-Viscosity of optical glasses-sphere method-Con.

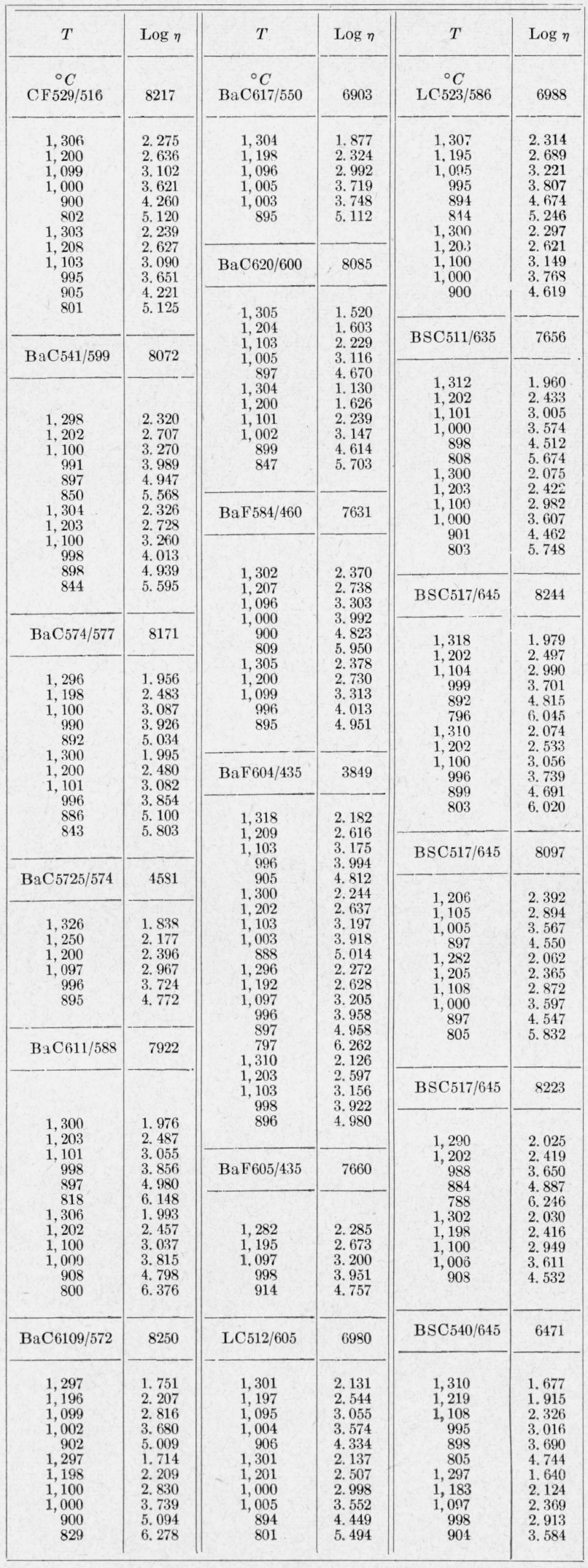

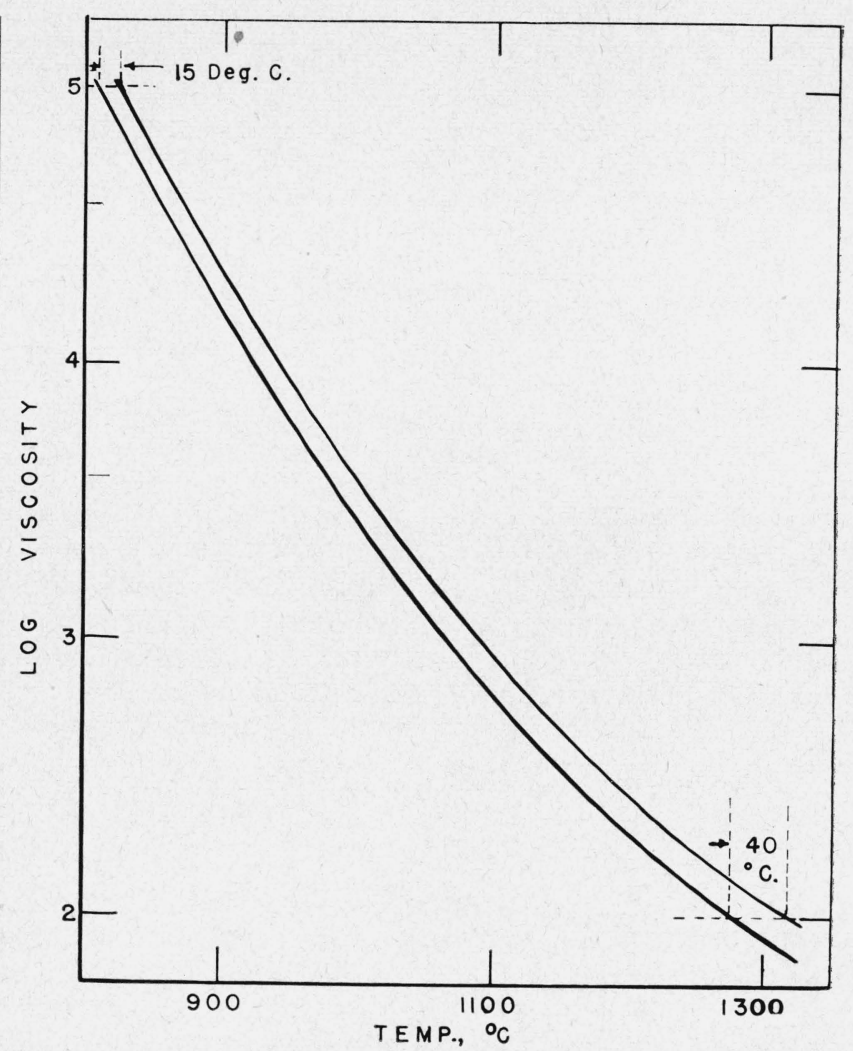

FIGURE 8. Idealized curves of log viscosity versus temperature.

The vertical distance between the two curves is the same throughout.

There are certain implications in the method of presenting viscosity data in the manner commonly done in the glass industry that are often overlooked. Statements frequently occur in the literature to the effect that the reproducibility is better in the low temperature range than in the high one. It is important to note that this assertion is a necessary consequence of the nature of the viscosity versus temperature curve. Figure 8 shows two hypothetical $\log$ viscosity versus temperature curves that are meant to represent two determinations on the same glass. The separation between the curves has been deliberately exaggerated, and the assumption has been made that the percentage difference in viscosity between the two sets of determinations at any given temperature is constant. This procedure is equivalent to finding that the difference in log viscosity of the two curves is the same at any temperature.

In spite of the fact that the vertical differences between the two curves are always the same, the curves appear to come closer together as the viscosity rises. The eye judges the distance between the two curves by their separation along a perpendicular to the curves themselves rather than either the vertical or horizontal distance. As the curves become steeper their perpendiculars become more nearly horizontal, and the eye sees the separation more and more along the horizontal, that is, the temperature difference. The vertical separation can increase and yet, depending upon the slope of the viscosity-temperature curve, 
TABLE 4. Viscosities of optical glasses by sphere method

$\mathrm{F}=$ Flint $\mathrm{BaC}=$ barium crown; $\mathrm{LC}=$ light crown; $\mathrm{BaF}=$ barium flint; $\mathrm{BSC}=$ borosilicate crown; $\mathrm{CF}=$ erown flint. $\quad$ Values in brackets are extrapolated

\begin{tabular}{|c|c|c|c|c|c|c|c|c|c|c|c|}
\hline \multirow{2}{*}{ Glass type } & \multirow{2}{*}{ Melt } & \multicolumn{10}{|c|}{ Temperature, ${ }^{\circ} \mathrm{C}$, at which $\log \eta$ is- } \\
\hline & & 1,5 & 2.0 & 2.5 & 3.0 & 3.5 & 4. 0 & 4.5 & 5.0 & 5.5 & 6.0 \\
\hline \multirow[t]{2}{*}{ F $5795 / 410 \ldots$} & \multirow{2}{*}{$\begin{array}{l}\text { A verage } \\
\text { From average curve }\end{array}$} & & -..... & $\left\{\begin{array}{c}1,305 \\
1,259 \\
{[1,304]}\end{array}\right.$ & $\begin{array}{l}1,184 \\
1,189 \\
1,192\end{array}$ & $\begin{array}{l}1,080 \\
1.085 \\
1,083\end{array}$ & $\begin{array}{r}999 \\
1,003 \\
999\end{array}$ & $\begin{array}{l}930 \\
934 \\
929\end{array}$ & $\begin{array}{l}872 \\
874 \\
{[871]}\end{array}$ & $\begin{array}{l}826 \\
823 \\
-\end{array}$ & (n) \\
\hline & & - & 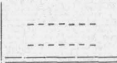 & $\begin{array}{l}1,302 \\
1,304 \\
\end{array}$ & $\begin{array}{l}1,188 \\
1,185 \\
\end{array}$ & $\begin{array}{l}1,083 \\
1,083 \\
\end{array}$ & $\begin{array}{l}1,000 \\
1,000 \\
\end{array}$ & $\begin{array}{l}931 \\
930 \\
\end{array}$ & $\begin{array}{l}873 \\
875 \\
\end{array}$ & $\begin{array}{r}824 \\
828 \\
\end{array}$ & 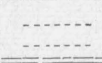 \\
\hline \multirow[t]{2}{*}{ F $617 / 366$} & \multirow{2}{*}{$\begin{array}{l}\text { A verage } \\
\text { From a verage curve }\end{array}$} & & $\left\{\begin{array}{l}1,255 \\
1,258\end{array}\right.$ & $\begin{array}{l}1,113 \\
1,117 \\
\end{array}$ & $\begin{array}{l}1,010 \\
1,007\end{array}$ & $\begin{array}{l}922 \\
921 \\
\end{array}$ & $\begin{array}{l}851 \\
852 \\
\end{array}$ & $\begin{array}{l}793 \\
793 \\
\end{array}$ & $\begin{array}{l}751 \\
746 \\
\end{array}$ & 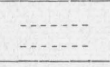 & . \\
\hline & & . & 1,256 & $\begin{array}{l}1,115 \\
1,117 \\
\end{array}$ & $\begin{array}{l}1,008 \\
1,008 \\
\end{array}$ & $\begin{array}{l}922 \\
922 \\
\end{array}$ & $\begin{array}{l}852 \\
850 \\
\end{array}$ & $\begin{array}{l}793 \\
794 \\
\end{array}$ & $\begin{array}{l}748 \\
748 \\
\end{array}$ & - n & . \\
\hline \multirow[t]{2}{*}{ F $620 / 362$} & \multirow{2}{*}{$\begin{array}{l}\text { Average } \\
\text { From average curve }\end{array}$} & $\cdots$ & $\left\{\begin{array}{l}1,307 \\
i \quad 1,293 \\
\end{array}\right.$ & $\begin{array}{l}1,157 \\
1,168\end{array}$ & $\begin{array}{l}1,054 \\
1,056\end{array}$ & $\begin{array}{l}967 \\
962\end{array}$ & $\begin{array}{l}892 \\
890\end{array}$ & $\begin{array}{l}830 \\
831\end{array}$ & 776 & (n........ & (n...... \\
\hline & & 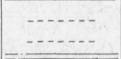 & $\begin{array}{r}1,300 \\
1,292 \\
\end{array}$ & $\begin{array}{l}1,162 \\
1,163 \\
\end{array}$ & $\begin{array}{l}1,055 \\
1,055 \\
\end{array}$ & $\begin{array}{l}964 \\
964 \\
\end{array}$ & $\begin{array}{l}891 \\
889 \\
\end{array}$ & $\begin{array}{l}830 \\
830 \\
\end{array}$ & 775 & - & (n....... \\
\hline \multirow[t]{2}{*}{ F $649 / 338$} & $8187 \ldots$ & -.... & $\begin{array}{l}1,267 \\
1,279\end{array}$ & $\begin{array}{l}1,149 \\
1,152\end{array}$ & $\begin{array}{l}1,044 \\
1,044\end{array}$ & $\begin{array}{l}956 \\
958 \\
\end{array}$ & $\begin{array}{l}877 \\
888\end{array}$ & $\begin{array}{l}828 \\
828\end{array}$ & 780 & 738 & (n..... \\
\hline & $\begin{array}{l}\text { Average } \\
\text { From average curve }\end{array}$ & (n) & $\begin{array}{l}1,273 \\
1,274 \\
\end{array}$ & $\begin{array}{l}1,150 \\
1,147 \\
\end{array}$ & $\begin{array}{l}1,044 \\
1,033 \\
\end{array}$ & $\begin{array}{l}957 \\
958 \\
\end{array}$ & $\begin{array}{l}882 \\
885 \\
\end{array}$ & $\begin{array}{l}828 \\
827 \\
\end{array}$ & 780 & (n) & (n. \\
\hline \multirow[t]{2}{*}{ F $666 / 324 \ldots . . .}$. & $7686 \ldots$ & & $\left\{\begin{array}{l}1,265 \\
1,270\end{array}\right.$ & $\begin{array}{l}1,143 \\
1,137\end{array}$ & $\begin{array}{l}1,034 \\
1,029 \\
\end{array}$ & $\begin{array}{l}954 \\
947 \\
\end{array}$ & $\begin{array}{l}889 \\
881\end{array}$ & $\begin{array}{l}833 \\
828\end{array}$ & $\begin{array}{l}786 \\
782\end{array}$ & $\begin{array}{l}744 \\
741\end{array}$ & (n...... \\
\hline & $\begin{array}{l}\text { A verage } \\
\text { From average clirve }\end{array}$ & (n) & $\begin{array}{r}1,268 \\
1,267 \\
\end{array}$ & $\begin{array}{l}1,140 \\
1,141 \\
\end{array}$ & $\begin{array}{l}1,032 \\
1,030 \\
\end{array}$ & $\begin{array}{l}950 \\
948 \\
\end{array}$ & $\begin{array}{l}885 \\
883 \\
\end{array}$ & $\begin{array}{l}830 \\
829 \\
\end{array}$ & $\begin{array}{l}784 \\
782 \\
\end{array}$ & $\begin{array}{l}742 \\
743 \\
\end{array}$ & (n) \\
\hline \multirow[t]{2}{*}{ F $689 / 309 \ldots$} & 7382 & & $\left\{\begin{array}{l}1,240 \\
1,233\end{array}\right.$ & $\begin{array}{l}1,111 \\
1,111\end{array}$ & $\begin{array}{l}1,012 \\
1,012\end{array}$ & $\begin{array}{l}931 \\
931 \\
\end{array}$ & $\begin{array}{l}859 \\
859\end{array}$ & $\begin{array}{l}806 \\
808\end{array}$ & $\begin{array}{l}763 \\
764\end{array}$ & 730 & (n. \\
\hline & $\begin{array}{l}\text { Average } \\
\text { From average curve }\end{array}$ & (n... & $\begin{array}{l}1,236 \\
1,233 \\
\end{array}$ & $\begin{array}{l}1,111 \\
1,111\end{array}$ & $\begin{array}{l}1,012 \\
1,010\end{array}$ & $\begin{array}{l}931 \\
926 \\
\end{array}$ & $\begin{array}{l}859 \\
856\end{array}$ & $\begin{array}{l}807 \\
806\end{array}$ & $\begin{array}{l}764 \\
764\end{array}$ & (n........ & (n) \\
\hline \multirow[t]{2}{*}{ F $720 / 293 \ldots$} & 7728 & $\left\{\begin{array}{c}1,293 \\
-\end{array}\right.$ & $\begin{array}{l}1,178 \\
1,174\end{array}$ & $\begin{array}{l}1,056 \\
1,051\end{array}$ & $\begin{array}{l}965 \\
958 \\
\end{array}$ & $\begin{array}{l}890 \\
884 \\
\end{array}$ & $\begin{array}{l}828 \\
828\end{array}$ & $\begin{array}{l}779 \\
781 \\
\end{array}$ & $\begin{array}{l}739 \\
741\end{array}$ & $\begin{array}{l}704 \\
704\end{array}$ & - \\
\hline & From average curve & 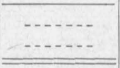 & $\begin{array}{l}1,176 \\
1,174 \\
\end{array}$ & $\begin{array}{l}1,054 \\
1,054 \\
\end{array}$ & $\begin{array}{l}962 \\
964 \\
\end{array}$ & $\begin{array}{l}887 \\
890 \\
\end{array}$ & $\begin{array}{l}828 \\
827 \\
\end{array}$ & $\begin{array}{l}780 \\
780 \\
\end{array}$ & $\begin{array}{l}740 \\
739 \\
\end{array}$ & $\begin{array}{l}704 \\
704 \\
\end{array}$ & (n) \\
\hline \multirow[t]{2}{*}{ F $754 / 277 \ldots$} & 8001 & $\left\{\begin{array}{l}1,223 \\
1,231\end{array}\right.$ & $\begin{array}{l}1,101 \\
1,096\end{array}$ & $\begin{array}{l}990 \\
986\end{array}$ & $\begin{array}{l}908 \\
902 \\
\end{array}$ & $\begin{array}{l}838 \\
838 \\
\end{array}$ & $\begin{array}{l}784 \\
780 \\
\end{array}$ & $\begin{array}{l}740 \\
740\end{array}$ & $\begin{array}{l}704 \\
702\end{array}$ & (n..... & (n...... \\
\hline & $\begin{array}{l}\text { Average } \\
\text { From average curve }\end{array}$ & $\begin{array}{r}1,227 \\
1,230 \\
\end{array}$ & $\begin{array}{l}1,098 \\
1,098\end{array}$ & $\begin{array}{l}988 \\
986 \\
\end{array}$ & $\begin{array}{l}905 \\
903\end{array}$ & $\begin{array}{l}838 \\
834 \\
\end{array}$ & $\begin{array}{l}782 \\
782 \\
\end{array}$ & $\begin{array}{l}740 \\
738 \\
\end{array}$ & $\begin{array}{l}703 \\
702 \\
\end{array}$ & +..... & $\begin{array}{ll}\ldots+\cdots \\
\cdots\end{array}$ \\
\hline \multirow[t]{2}{*}{ CF $529 / 516 \ldots$} & 8217 & & - n & $\left\{\begin{array}{l}1,235 \\
1,238 \\
\end{array}\right.$ & $\begin{array}{l}1,121 \\
1,122 \\
\end{array}$ & $\begin{array}{l}1,023 \\
1,022 \\
\end{array}$ & $\begin{array}{l}938 \\
938 \\
\end{array}$ & $\begin{array}{l}869 \\
870\end{array}$ & $\begin{array}{l}813 \\
814\end{array}$ & 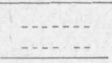 & (n....... \\
\hline & $\begin{array}{l}\text { A verage } \\
\text { From average curve }\end{array}$ & +..... & (n) & $\begin{array}{l}1,236 \\
1,237 \\
\end{array}$ & $\begin{array}{l}1,122 \\
1,122 \\
\end{array}$ & $\begin{array}{l}1,022 \\
1,020 \\
\end{array}$ & $\begin{array}{l}938 \\
937 \\
\end{array}$ & $\begin{array}{l}870 \\
872 \\
\end{array}$ & $\begin{array}{l}814 \\
814 \\
\end{array}$ & (n) & (n) \\
\hline \multirow[t]{2}{*}{$\mathrm{BaC} 541 / 599 \ldots$} & 8072 & $\cdots$ & (n) & $\left\{\begin{array}{l}1,250 \\
1,259\end{array}\right.$ & $\begin{array}{l}1,147 \\
1,146\end{array}$ & $\begin{array}{l}1,063 \\
1,066\end{array}$ & $\begin{array}{r}991 \\
1,000 \\
\end{array}$ & $\begin{array}{l}937 \\
942 \\
\end{array}$ & $\begin{array}{l}892 \\
892 \\
\end{array}$ & $\begin{array}{l}855 \\
851 \\
\end{array}$ & - \\
\hline & $\begin{array}{l}\text { Average } \\
\text { From average curve }\end{array}$ & (n) & (n) & $\begin{array}{l}1,254 \\
1,252 \\
\end{array}$ & $\begin{array}{r}1,146 \\
1,147 \\
\end{array}$ & $\begin{array}{l}1,064 \\
1,064\end{array}$ & $\begin{array}{l}996 \\
995 \\
\end{array}$ & $\begin{array}{l}940 \\
938 \\
\end{array}$ & $\begin{array}{l}892 \\
893 \\
\end{array}$ & $\begin{array}{l}853 \\
853 \\
\end{array}$ & (n. \\
\hline $\mathrm{BaC} 5725 / 574$ & $4581 \ldots$ & 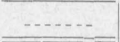 & 1,289 & 1,181 & 1,091 & 1,020 & 969 & 924 & 886 & $\ldots \ldots$ & .......... \\
\hline \multirow[t]{2}{*}{$\mathrm{BaC} 574 / 577 \ldots$} & 8171 & $\cdots$ & $\left\{\begin{array}{l}1,286 \\
1,299\end{array}\right.$ & $\begin{array}{l}1,195 \\
1,197\end{array}$ & $\begin{array}{l}1,113 \\
1,113\end{array}$ & $\begin{array}{l}1,039 \\
1,041\end{array}$ & $\begin{array}{l}982 \\
981\end{array}$ & $\begin{array}{l}935 \\
934\end{array}$ & $\begin{array}{l}895 \\
893\end{array}$ & 860 & 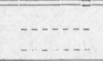 \\
\hline & $\begin{array}{l}\text { Average } \\
\text { From average curve }\end{array}$ & - & $\begin{array}{l}1,292 \\
1,292 \\
\end{array}$ & $\begin{array}{l}1,196 \\
1,196\end{array}$ & $\begin{array}{l}1,113 \\
1,114\end{array}$ & $\begin{array}{l}1,040 \\
1,040\end{array}$ & $\begin{array}{l}982 \\
980\end{array}$ & $\begin{array}{l}934 \\
932\end{array}$ & $\begin{array}{l}894 \\
894\end{array}$ & 860 & (n....... \\
\hline \multirow[t]{2}{*}{$\mathrm{BaC} 6109 / 572$} & 8250 & & $\left\{\begin{array}{l}1,237 \\
1,236\end{array}\right.$ & $\begin{array}{l}1,146 \\
1,148\end{array}$ & $\begin{array}{l}1,076 \\
1,079\end{array}$ & $\begin{array}{l}1,019 \\
1,023\end{array}$ & $\begin{array}{l}974 \\
978 \\
\end{array}$ & $\begin{array}{l}936 \\
939 \\
\end{array}$ & $\begin{array}{l}903 \\
906\end{array}$ & 874 & 844 \\
\hline & $\begin{array}{l}\text { A verage } \\
\text { From average curve }\end{array}$ & (n) & $\begin{array}{l}1,236 \\
1,236 \\
\end{array}$ & $\begin{array}{l}1,147 \\
1,148 \\
\end{array}$ & $\begin{array}{l}1,078 \\
1,076\end{array}$ & $\begin{array}{l}1,021 \\
1,021 \\
\end{array}$ & $\begin{array}{l}976 \\
974 \\
\end{array}$ & $\begin{array}{l}938 \\
937 \\
\end{array}$ & $\begin{array}{l}904 \\
904\end{array}$ & 875 & 844 \\
\hline \multirow[t]{2}{*}{$\mathrm{BaC} 611 / 588 \ldots$} & 7922 & $\ldots$ & $\left\{\begin{array}{l}1,296 \\
1,304\end{array}\right.$ & $\begin{array}{l}1,200 \\
1,194\end{array}$ & $\begin{array}{l}1,111 \\
1,105\end{array}$ & $\begin{array}{l}1,038 \\
1,036\end{array}$ & $\begin{array}{l}983 \\
980\end{array}$ & $\begin{array}{l}935 \\
932\end{array}$ & $\begin{array}{l}895 \\
892\end{array}$ & $\begin{array}{l}859 \\
856\end{array}$ & $\begin{array}{l}826 \\
822\end{array}$ \\
\hline & $\begin{array}{l}\text { A verage } \\
\text { From average curve }\end{array}$ & (n) & $\begin{array}{l}1,300 \\
1,300 \\
\end{array}$ & $\begin{array}{l}1,198 \\
1,196 \\
\end{array}$ & $\begin{array}{l}1,108 \\
1,109 \\
\end{array}$ & $\begin{array}{l}1,037 \\
1,036\end{array}$ & $\begin{array}{l}982 \\
981\end{array}$ & $\begin{array}{l}934 \\
934\end{array}$ & $\begin{array}{l}894 \\
894 \\
\end{array}$ & $\begin{array}{l}858 \\
859 \\
\end{array}$ & $\begin{array}{l}824 \\
826\end{array}$ \\
\hline $\mathrm{BaC} 617 / 550 \ldots$ & 6903 & - & 1,271 & 1,162 & 1,086 & 1,028 & 981 & 940 & 903 & (n) & - n \\
\hline \multirow[t]{2}{*}{$\mathrm{BaC} 620 / 600 \ldots$} & 8085 & $\left\{\begin{array}{l}1,221 \\
1,222\end{array}\right.$ & $\begin{array}{l}1,136 \\
1,136\end{array}$ & $\begin{array}{l}1,066 \\
1,069\end{array}$ & $\begin{array}{l}1,010 \\
1,015\end{array}$ & $\begin{array}{l}969 \\
972\end{array}$ & $\begin{array}{l}935 \\
937 \\
\end{array}$ & $\begin{array}{l}906 \\
905\end{array}$ & 878 & 856 & (n) \\
\hline & $\begin{array}{l}\text { A verage } \\
\text { From average curve }\end{array}$ & $\begin{array}{l}1,222 \\
1,226 \\
\end{array}$ & $\begin{array}{l}1,136 \\
1,134 \\
\end{array}$ & $\begin{array}{l}1,068 \\
1,068 \\
\end{array}$ & $\begin{array}{l}1,012 \\
1,015 \\
\end{array}$ & $\begin{array}{l}970 \\
972\end{array}$ & $\begin{array}{l}936 \\
937\end{array}$ & $\begin{array}{l}906 \\
906\end{array}$ & 879 & 856 & - \\
\hline \multirow[t]{4}{*}{ BaF 584/460 ... } & 7631 & -- & - & $\left\{\begin{array}{l}1,265 \\
1,258\end{array}\right.$ & $\begin{array}{l}1,153 \\
1,152 \\
\end{array}$ & $\begin{array}{l}1,061 \\
1,069\end{array}$ & $\begin{array}{l}987 \\
998 \\
\end{array}$ & $\begin{array}{l}932 \\
940 \\
\end{array}$ & $\begin{array}{c}885 \\
{[889]}\end{array}$ & 843 & (no \\
\hline & From average curve & - & (n) & $\begin{array}{l}1,262 \\
1,265 \\
\end{array}$ & $\begin{array}{l}1,152 \\
1,152 \\
\end{array}$ & $\begin{array}{l}1,065 \\
1,069 \\
\end{array}$ & $\begin{array}{r}992 \\
1,000 \\
\end{array}$ & $\begin{array}{l}936 \\
940 \\
\end{array}$ & $\begin{array}{l}887 \\
887 \\
\end{array}$ & 843 & {$[806]$} \\
\hline & 3849 & & - & $\left\{\begin{array}{l}1,236 \\
1,232 \\
1,220 \\
1,223\end{array}\right.$ & $\begin{array}{l}1,135 \\
1,135 \\
1,128 \\
1,129 \\
\end{array}$ & $\begin{array}{l}1,058 \\
1,058 \\
1,054 \\
1,051\end{array}$ & $\begin{array}{l}995 \\
993 \\
992 \\
989 \\
\end{array}$ & $\begin{array}{l}939 \\
939 \\
939 \\
939 \\
\end{array}$ & $\begin{array}{c}886 \\
890 \\
893 \\
{[894]} \\
\end{array}$ & 851 & 817 \\
\hline & $\begin{array}{l}\text { Average } \\
\text { From average curve }\end{array}$ & - & (n) & $\begin{array}{l}1,228 \\
1,235 \\
\end{array}$ & $\begin{array}{l}1,132 \\
1,135 \\
\end{array}$ & $\begin{array}{l}1,055 \\
1,054 \\
\end{array}$ & $\begin{array}{l}992 \\
991\end{array}$ & $\begin{array}{l}939 \\
937 \\
\end{array}$ & $\begin{array}{l}891 \\
892 \\
\end{array}$ & (n) & (n...... \\
\hline
\end{tabular}


TABLE 4. Viscosities of optical glasses by sphere method-Continued

$\mathrm{F}=$ Flint $\mathrm{BaC}=$ barium crown; $\mathrm{LC}=$ light crown; $\mathrm{BaF}=$ barium flint; $\mathrm{BSC}=$ borosilicate crown $\mathrm{CF}=$ crown flint. Values in brackets are extrapolated

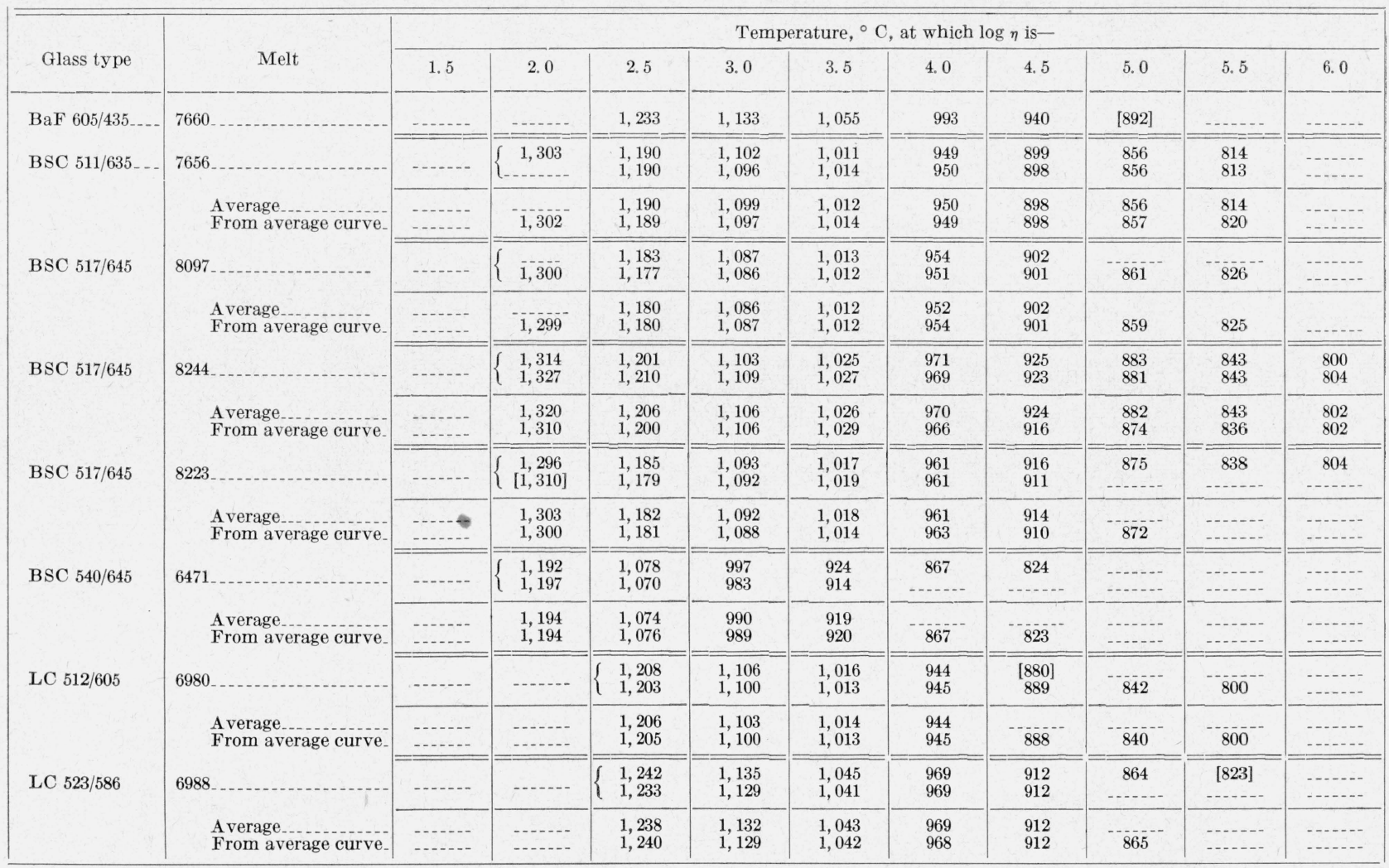

TABLE 5. Viscosity of optical glasses by rotational viscometer

$\mathrm{F}=$ flint $; \mathrm{BaC}=$ barium crown $\mathrm{LC}=$ light crown; $\mathrm{BSC}=$ borosilicate crown

\begin{tabular}{|c|c|c|c|c|c|}
\hline$T$ & $\log \eta$ & $T$ & $\log \eta$ & $T$ & $\log \eta$ \\
\hline F $5795 / 410$ & 5613 & F $649 / 338$ & 4438 & $\mathrm{BaC} 617 / 550$ & 5815 \\
\hline \multirow{6}{*}{$\begin{array}{c}{ }^{\circ} C \\
1,102 \\
1,052 \\
1,002 \\
954 \\
902 \\
853 \\
798\end{array}$} & \multirow{6}{*}{$\begin{array}{l}3.394 \\
3.695 \\
4.013 \\
4.387 \\
4.813 \\
5.231 \\
5.792\end{array}$} & \multirow{8}{*}{$\begin{array}{r}{ }^{\circ} C \\
1,110 \\
1,054 \\
993 \\
995 \\
949 \\
948 \\
904 \\
852 \\
805 \\
756\end{array}$} & \multirow{8}{*}{$\begin{array}{l}2.700 \\
2.988 \\
3.336 \\
3.335 \\
3.635 \\
3.631 \\
3.945 \\
4.411 \\
4.859 \\
5.502\end{array}$} & ${ }^{\circ} \mathrm{C}$ & \\
\hline & & & & 999 & 4. 003 \\
\hline & & & & 951 & 4.548 \\
\hline & & & & & \\
\hline & & & & LC $523 / 586$ & 5718 \\
\hline & & & & 1,094 & 3.214 \\
\hline F $617 / 366$ & 5617 & & & $\begin{array}{l}1,053 \\
1,003\end{array}$ & $\begin{array}{l}3.458 \\
3.785\end{array}$ \\
\hline \multirow{7}{*}{$\begin{array}{r}1,096 \\
1,050 \\
998 \\
951 \\
902 \\
850 \\
799 \\
751\end{array}$} & \multirow{7}{*}{$\begin{array}{l}2.649 \\
2.876 \\
3.119 \\
3.403 \\
3.705 \\
4.096 \\
4.504 \\
4.991\end{array}$} & & & 954 & 4. 172 \\
\hline & & \multirow[t]{2}{*}{$\mathrm{BaC} 5725 / 574$} & \multirow[t]{2}{*}{4581} & & \\
\hline & & & & BSC $511 / 635$ & 5407 \\
\hline & & \multirow{9}{*}{$\begin{array}{r}1,101 \\
1,049 \\
998 \\
952 \\
899 \\
851 \\
1,101 \\
1,048 \\
1,002 \\
953 \\
902 \\
850\end{array}$} & \multirow{9}{*}{$\begin{array}{l}2.942 \\
3.293 \\
3.675 \\
4.129 \\
4.743 \\
5.409 \\
2.917 \\
3.292 \\
3.649 \\
4.112 \\
4.688 \\
5.392\end{array}$} & 1,100 & 2.985 \\
\hline & & & & 1,047 & 3.308 \\
\hline & & & & 999 & 3. 649 \\
\hline & & & & 949 & 4.090 \\
\hline F $620 / 362$ & 5573 & & & $\begin{array}{l}902 \\
848\end{array}$ & $\begin{array}{l}4.554 \\
5.147\end{array}$ \\
\hline \multirow{6}{*}{$\begin{array}{r}1,098 \\
1,048 \\
1,000 \\
953 \\
903 \\
854 \\
802 \\
755\end{array}$} & \multirow{6}{*}{$\begin{array}{l}2.740 \\
2.986 \\
3.222 \\
3.496 \\
3.839 \\
4.220 \\
4.708 \\
5.164\end{array}$} & & & 799 & 5.806 \\
\hline & & & & BSC $517 / 645$ & 5371 \\
\hline & & & & 1,099 & 2875 \\
\hline & & & & $\begin{array}{l}1,099 \\
1,096\end{array}$ & $\begin{array}{l}2.875 \\
2.884\end{array}$ \\
\hline & & $\mathrm{BaC} 611 / 588$ & \multirow[t]{2}{*}{5666} & 1,051 & 3.153 \\
\hline & & \multirow{5}{*}{$\begin{array}{r}1,101 \\
1,048 \\
1,006 \\
952 \\
905 \\
847\end{array}$} & & 953 & $\begin{array}{l}3.532 \\
3.931\end{array}$ \\
\hline F $649 / 338$ & 4438 & & \multirow{4}{*}{$\begin{array}{l}2.248 \\
2.727 \\
3.138 \\
3.751 \\
4.436 \\
5.547\end{array}$} & $\begin{array}{l}901 \\
850\end{array}$ & $\begin{array}{l}4.482 \\
5.140\end{array}$ \\
\hline 1,102 & 2. 726 & & & $\begin{array}{r}800 \\
1,091\end{array}$ & $\begin{array}{l}5.862 \\
2.899\end{array}$ \\
\hline 1,044 & 3. 008 & & & 1,054 & $\begin{array}{l}2.899 \\
3.156\end{array}$ \\
\hline 992 & 3. 290 & & & 1,004 & 3.517 \\
\hline $\begin{array}{l}955 \\
896\end{array}$ & $\begin{array}{l}3.538 \\
3.957\end{array}$ & $\mathrm{BaC} 617 / 550$ & 5815 & $\begin{array}{l}951 \\
904\end{array}$ & $\begin{array}{l}3.967 \\
4.459\end{array}$ \\
\hline 854 & 4. 315 & & & $\begin{array}{l}850 \\
814\end{array}$ & 5. 120 \\
\hline $\begin{array}{l}799 \\
754\end{array}$ & $\begin{array}{l}4.882 \\
5.389\end{array}$ & $\begin{array}{l}1,098 \\
1,052\end{array}$ & $\begin{array}{l}3.100 \\
3.485\end{array}$ & $\begin{array}{l}814 \\
800\end{array}$ & $\begin{array}{l}5.662 \\
5.869\end{array}$ \\
\hline
\end{tabular}

the curves will appear to come closer together. Thus the reproducibility in the high viscosity range may actually become worse and yet appear better when expressed as a temperature difference at the same viscosity. In figure 8 the reproducibility is constant, yet one can readily see that whereas the temperature difference at $\log \eta=2$ is $40 \mathrm{deg} \mathrm{C}$, that at $\log \eta=5$ is only $15 \mathrm{deg} \mathrm{C}$.

\section{Rotational Viscometer Data}

Preliminary measurements were made with a small rotation viscometer, which has already been described in the literature [7]. This apparatus was limited to measurements below $1,100^{\circ} \mathrm{C}$. Table 5 gives the results obtained, and table 6 shows these results in terms of temperature at certain selected viscosities as obtained by interpolation from smooth curves.

\section{Comparison of Sphere and Rotational Viscometer Data}

Table 7 gives a comparison between the results obtained with the rotation and sphere methods. Of the four glasses with nominally identical compositions, $\mathrm{BaC} 617$ glass shows up as the worst; and all attempts to find the cause for the extreme deviation in this case proved fruitless. No additional sample of melt 5815 was available, so the possibility of an error could not be verified. The other three glasses where direct comparison is possible show fair agreement, the average difference between them being 5 deg. 
TABLE 6. Viscosity of optical glasses by rotational viscometer

$\mathrm{F}=$ flint $; \mathrm{BaC}=$ barium crown $\mathrm{LC}=$ light crown; $\mathrm{BSC}=$ borosilicate crown. Figures in brackets are extrapolated values

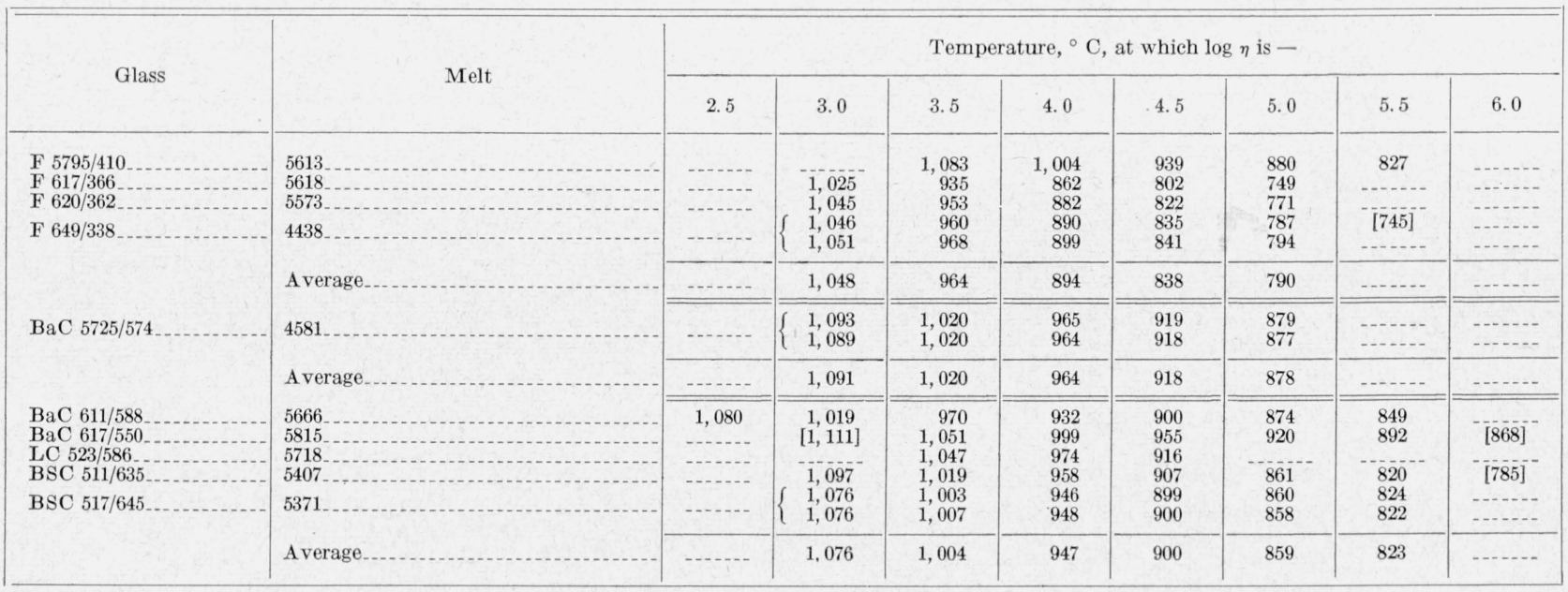

TABLE 7. Viscosity of optical glasses

$\mathrm{F}=$ flint $; \mathrm{BaC}=$ barium crown; $\mathrm{LC}=$ light crown; $\mathrm{BSC}=$ borosilicate crown. Figures in brackets are extrapolated values

\begin{tabular}{|c|c|c|c|c|c|c|c|c|c|}
\hline \multirow{2}{*}{ Glass } & \multirow{2}{*}{ Melt } & \multirow{2}{*}{ Method of measurement } & \multicolumn{7}{|c|}{ Temperature, ${ }^{\circ} \mathrm{C}$, at which $\log \eta$ is- } \\
\hline & & & 2.5 & 3.0 & 3.5 & 4.0 & 4.5 & 5.0 & 5.5 \\
\hline
\end{tabular}

a Nominally identical compositions.

The effect of composition differences on the viscosity of glasses causes difficulty in comparing results of the two methods. However, in some cases the differences in composition are so small that a comparison seems valid. Thus, considering F 5795 the average differences between the two methods is about $5 \mathrm{deg}$ because only small differences in composition are present (table 1). In the case of $\mathrm{F} 617$ the only apparent difference is a substitution of 0.3 percent of $\mathrm{Na}_{2} \mathrm{O}$ for $\mathrm{K}_{2}, \mathrm{O}$ but melt 5618 has $775 \mathrm{lb}$ of cullet to only $300 \mathrm{lb}$ for melt 7045 . This means that 5618 probably has more alumina and may account for its higher viscosity at the higher temperatures. In the case of F 620 there has been a substitution of 0.5 percent of $\mathrm{Na}_{2} \mathrm{O}$ for $\mathrm{K}_{2} \mathrm{O}$ in melt 5573 as compared to 8197 . The effect of such substitutions is hard to predict because it has been shown [9] that such substitutions may either raise or lower the viscosity, depending upon the composition of the base glass. In this case the substitution of $\mathrm{Na}_{2} \mathrm{O}$ for $\mathrm{K}_{2} \mathrm{O}$ lowered the viscosity. In the case of $\mathrm{BaC} 611$ melt 7922 would be expected to be more viscous than melt 5666 because it has 0.5 percent more $\mathrm{Al}_{2} \mathrm{O}_{3}$ and 0.5 percent less $\mathrm{CaO}$. However, the difference is very large in the high-temperature range and the fact that $475 \mathrm{lb}$ of cullet was used in melt 7922 , whereas the fact that none was used in 5666 helps to account for this. In the case of BSC 517 the compositions are considerably different, so that comparison between the two methods is not valid. Melts 8097 and 8223 have nominally identical compositions, but the latter melt had $250 \mathrm{lb}$ more cullet than the former and therefore shows the higher viscosity. 


\section{Density Results}

\section{Sphere Method}

Figure 9 shows a plot of the density of the calibrating liquid versus temperature. The straight line represents densities obtained by a picnometer method. The circles represent the density data obtained with the restrained falling sphere apparatus. The average deviation of the circles from the straight line is about 5 in the fourth significant figure.

Table 8 gives interpolated values of density of optical glasses at 100-deg C intervals obtained with the restrained sphere method. Densities of glasses at room temperature were obtained by measuring the buoyant effect of distilled water. The average difference between nominally duplicate determinations at $1,300^{\circ}$ and $1,200^{\circ} \mathrm{C}$ is about 3 in the fourth significant figure. This difference rises to about 5 at $1,100^{\circ}$ and $1,000^{\circ} \mathrm{C}$. At high viscosities (approximately 5,000 poises) the density results become unreliable.

The expansivities as computed from density changes in the range $1,000^{\circ}$ to $1,200^{\circ} \mathrm{C}$ are given in the last column of table 8 . The precision of these

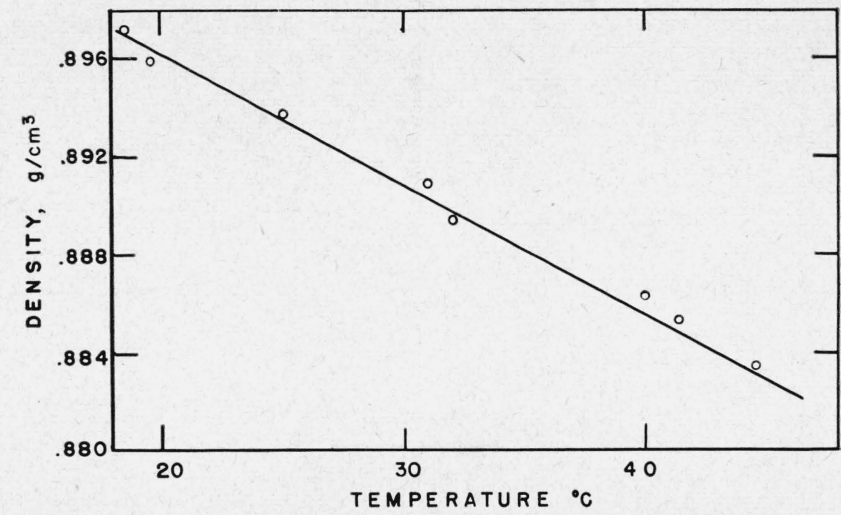

Figure 9. Density of calibrating liquid versus Centigrade temperature.

Circles represent restrained sphere data, straight line represents picnometer data.

expansivities is rather low. On the whole, the flints, barium flints, and crown flints have low expansivities, whereas the borosilicate crowns have high ones. The expansivities of the barium crowns show a general tendency to increase with index of refraction and density.

TABLE 8. Density and expansivity of molten optical glasses by sphere method

$\mathrm{F}=$ flint $\mathrm{BaC}=$ barium crown $\mathrm{LC}=$ light crown $; \mathrm{BaF}=$ barium flint; $\mathrm{BSC}=$ borosilicate crown; $\mathrm{CF}=$ crown flint

\begin{tabular}{|c|c|c|c|c|c|c|c|c|c|c|c|}
\hline \multirow[b]{2}{*}{ Glass } & \multirow{2}{*}{ Melt } & \multirow{2}{*}{$\begin{array}{l}\text { Deter- } \\
\text { mination } \\
\text { number }\end{array}$} & \multicolumn{8}{|c|}{ Density $\left(\mathrm{g} / \mathrm{cm}_{3}\right)$ at- } & \multirow{2}{*}{$\begin{array}{l}\text { Expansiv- } \\
\text { ity }\left(1,000^{\circ}\right. \\
\left.\text { to } 1,200^{\circ} \mathrm{C}\right)\end{array}$} \\
\hline & & & $1,300^{\circ} \mathrm{C}$ & $1,200^{\circ} \mathrm{C}$ & $1,100^{\circ} \mathrm{C}$ & $1,000^{\circ} \mathrm{C}$ & $900^{\circ} \mathrm{C}$ & $800^{\circ} \mathrm{C}$ & $700^{\circ} \mathrm{C}$ & Room & \\
\hline \multirow[t]{2}{*}{ F $5795 / 410 \ldots$} & \multirow[t]{2}{*}{7133} & $\left\{\begin{array}{l}1 \\
2 \ldots \ldots \ldots \\
3 \ldots \ldots \ldots\end{array}\right.$ & $\begin{array}{l}3.035 \\
3.040 \\
3.025 \\
\end{array}$ & $\begin{array}{l}\text { 3. } 046 \\
\text { 3. } 048 \\
\text { 3. } 037 \\
\end{array}$ & $\begin{array}{l}3.051 \\
3.058 \\
3.052 \\
\end{array}$ & $\begin{array}{r}\text { 3. } 076 \\
\text { 3. } 073 \\
-\end{array}$ & (n) & - & . & 3.230 & $\begin{array}{c}(\mu / m) /{ }^{\circ} \mathrm{C} \\
16\end{array}$ \\
\hline & & avg... & 3.033 & 3.044 & 3.054 & 3. 074 & ....... & -....... & ....... & -...... & -....... \\
\hline \multirow[t]{2}{*}{ F $617 / 366$} & \multirow[t]{2}{*}{7045} & $\left\{\begin{array}{l}1 \\
2 \ldots \ldots \ldots\end{array}\right.$ & $\begin{array}{l}\text { 3. } 271 \\
\text { 3. } 276\end{array}$ & $\begin{array}{l}\text { 3. } 289 \\
\text { 3. } 296\end{array}$ & $\begin{array}{l}3.307 \\
3.315\end{array}$ & $\begin{array}{l}\text { 3. } 330 \\
\text { 3. } 332\end{array}$ & $\begin{array}{l}3.347 \\
3.350\end{array}$ & $\begin{array}{c}3.362 \\
-\end{array}$ & .......... & 3.545 & $\begin{array}{c}19 \\
\end{array}$ \\
\hline & & $\operatorname{avg} \ldots \ldots$ & 3. 274 & 3. 292 & 3. 311 & 3.331 & 3.348 & -....... & ......... & ........ & ........ \\
\hline \multirow[t]{2}{*}{ F $620 / 362 \ldots$} & \multirow[t]{2}{*}{$8197 \ldots \ldots$} & $\left\{\begin{array}{l}1 \\
2 \ldots \ldots \ldots\end{array}\right.$ & $\begin{array}{l}3.346 \\
3.350 \\
\end{array}$ & $\begin{array}{l}3.357 \\
3.363 \\
\end{array}$ & $\begin{array}{l}3.375 \\
3.382 \\
\end{array}$ & $\begin{array}{l}\text { 3. } 388 \\
\text { 3. } 404\end{array}$ & $\begin{array}{l}3.406 \\
3.417 \\
\end{array}$ & - & n. & 3.602 & 19 \\
\hline & & avg & 3.348 & 3.360 & 3. 378 & 3. 396 & 3.412 & -...... & ......... & - & - n \\
\hline \multirow[t]{2}{*}{ F $649 / 338 \ldots$} & \multirow[t]{2}{*}{$\begin{array}{l}8187 \ldots \ldots \\
8189\end{array}$} & $1 \ldots \ldots$ & $\begin{array}{l}3.595 \\
3.598 \\
\end{array}$ & $\begin{array}{l}3.610 \\
3.611 \\
\end{array}$ & $\begin{array}{l}3.632 \\
3.630 \\
\end{array}$ & $\begin{array}{l}3.656 \\
3.650 \\
\end{array}$ & 3.670 & - & - & $\begin{array}{c}3.871 \\
-\end{array}$ & 20 \\
\hline & & avg ........ & 3. 596 & 3.610 & 3. 631 & 3. 653 & -..... & (n..... & (n..... & -...... & n...... \\
\hline \multirow[t]{2}{*}{ F $666 / 324$} & \multirow[t]{2}{*}{7686} & $\left\{\begin{array}{l}1 \\
2 \ldots \ldots \ldots\end{array}\right.$ & $\begin{array}{l}3.728 \\
3.734\end{array}$ & $\begin{array}{l}3.743 \\
3.747\end{array}$ & $\begin{array}{l}3.762 \\
3.767\end{array}$ & $\begin{array}{l}3.786 \\
3.790\end{array}$ & $\begin{array}{l}3.806 \\
3.800\end{array}$ & - & - & $\begin{array}{r}4.016 \\
\end{array}$ & 20 \\
\hline & & avg ........ & 3.731 & 3.745 & 3.764 & 3.788 & 3.803 & ....... & -...... & ....... & (n......... \\
\hline \multirow[t]{2}{*}{ F $689 / 305$} & \multirow[t]{2}{*}{7382} & $\left\{\begin{array}{l}1 \\
2\end{array}\right.$ & $\begin{array}{l}3.928 \\
3.932 \\
\end{array}$ & $\begin{array}{l}3.950 \\
3.952 \\
\end{array}$ & $\begin{array}{l}3.969 \\
3.973 \\
\end{array}$ & $\begin{array}{l}3.988 \\
3.993 \\
\end{array}$ & $\begin{array}{l}\text { 4. } 014 \\
\text { 4. } 016 \\
\end{array}$ & . & . & 4.219 & 18 \\
\hline & & avg ......... & 3.930 & 3.951 & 3.971 & 3.990 & 4.015 & $\ldots$ & $\ldots \ldots$ & $\ldots$ & -.......... \\
\hline \multirow[t]{2}{*}{ F $720 / 293 \ldots$} & \multirow[t]{2}{*}{7728} & $\left\{\begin{array}{l}1 \\
2 \ldots \ldots \ldots\end{array}\right.$ & $\begin{array}{l}\text { 4. } 172 \\
\text { 4. } 170 \\
\end{array}$ & $\begin{array}{l}4.194 \\
4.192 \\
\end{array}$ & $\begin{array}{l}\text { 4. } 218 \\
\text { 4. } 217\end{array}$ & $\begin{array}{l}\text { 4. } 243 \\
\text { 4. } 244 \\
\end{array}$ & $\begin{array}{l}\text { 4. } 274 \\
\text { 4. } 270 \\
\end{array}$ & - & ........ & $\begin{array}{c}4.491 \\
-\end{array}$ & $\begin{array}{c}20 \\
-\end{array}$ \\
\hline & & avg ...... & 4. 171 & 4. 193 & 4. 218 & 4. 244 & 4. 272 & ........ & ......... & ......... & - n \\
\hline \multirow[t]{2}{*}{ F $754 / 277$} & \multirow[t]{2}{*}{$8001 \ldots$} & $\left\{\begin{array}{l}1 \\
2\end{array}\right.$ & $\begin{array}{l}\text { 4. } 414 \\
\text { 4. } 414 \\
\end{array}$ & $\begin{array}{l}4.440 \\
4.440 \\
\end{array}$ & $\begin{array}{l}4.466 \\
4.468 \\
\end{array}$ & $\begin{array}{l}4.496 \\
4.499 \\
\end{array}$ & $\begin{array}{l}\text { 4. } 522 \\
\text { 4. } 529 \\
\end{array}$ & $\begin{array}{l}4.566 \\
4.557 \\
\end{array}$ & 4.591 & 4.776 & 22 \\
\hline & & avg ....... & 4.414 & 4. 440 & 4. 467 & 4.498 & 4. 526 & 4. 562 & -...... & -...... & - n \\
\hline \multirow{3}{*}{$\begin{array}{l}\text { F } 923 / 209 \\
\text { CF } 529 / 516 \ldots\end{array}$} & \multirow{3}{*}{$8162 \ldots$} & $1 \ldots \ldots$ & ....... & ....... & 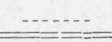 & ....... & …...... & 5. 737 & 5. 772 & 5.977 & ……. \\
\hline & & $\left\{\begin{array}{l}1 \\
2 \ldots \ldots \ldots\end{array}\right.$ & $\begin{array}{l}2.492 \\
2.482 \\
\end{array}$ & $\begin{array}{l}2.504 \\
2.504 \\
\end{array}$ & $\begin{array}{l}2.509 \\
2.515 \\
\end{array}$ & $\begin{array}{l}2.522 \\
2.528 \\
\end{array}$ & $\begin{array}{l}2.536 \\
2.542 \\
\end{array}$ & - & - & $\begin{array}{c}2.708 \\
-\end{array}$ & $\begin{array}{c}16 \\
-\end{array}$ \\
\hline & & avg ....... & 2. 486 & 2. 504 & 2.512 & 2. 525 & 2. 539 & -...... & -....... & - n. & - n \\
\hline
\end{tabular}


TABLE 8. Density and expansivity of molten optical glasses by sphere method-Continued

$\mathrm{F}=$ flint $; \mathrm{BaC}=$ barium crown; $\mathrm{LC}=$ light crown; $\mathrm{BaF}=$ barium flint; $\mathrm{BSC}=$ borosilicate crown; $\mathrm{CF}=$ crown flint

\begin{tabular}{|c|c|c|c|c|c|c|c|c|c|c|c|}
\hline \multirow{2}{*}{ Glass } & \multirow{2}{*}{ Melt } & \multirow{2}{*}{$\begin{array}{l}\text { Deter- } \\
\text { mination } \\
\text { number }\end{array}$} & \multicolumn{8}{|c|}{ Density $\left(\mathrm{g} / \mathrm{cm}^{3}\right)$ at -} & \multirow{2}{*}{$\begin{array}{l}\text { Expansiv- } \\
\text { ity }\left(1,000^{\circ}\right. \\
\left.\text { to } 1,200^{\circ} \mathrm{C}\right)\end{array}$} \\
\hline & & & $1,300^{\circ} \mathrm{C}$ & $1,200^{\circ} \mathrm{C}$ & $1,100^{\circ} \mathrm{C}$ & $1,000^{\circ} \mathrm{C}$ & $900^{\circ} \mathrm{C}$ & $800^{\circ} \mathrm{C}$ & $700^{\circ} \mathrm{C}$ & Room & \\
\hline \multirow[t]{2}{*}{$\mathrm{BaC} 541 / 599 \ldots$} & \multirow[t]{2}{*}{8072} & $\left\{\begin{array}{l}1 \\
2\end{array}\right.$ & $\begin{array}{l}\text { 2. } 580 \\
\text { 2. } 580 \\
\end{array}$ & $\begin{array}{l}\text { 2. } 607 \\
\text { 2. } 602 \\
\end{array}$ & $\begin{array}{l}2.620 \\
2.617 \\
\end{array}$ & -...... & (n).... & - & - & $\begin{array}{r}2.854 \\
-\end{array}$ & $\begin{array}{c}(\mu / m) /{ }^{\circ} \mathrm{C} \\
25\end{array}$ \\
\hline & & avg ....... & 2. 580 & 2. 604 & 2.618 & $\ldots$ & ........ & -....... & ........ & ........ & -....... \\
\hline $\mathrm{BaC} 5725 / 574$ & 4581 & $1 \ldots \ldots$ & 2. 831 & 2.858 & 2.882 & 2.895 & $\ldots$ & $\ldots$ & $\ldots$ & $\ldots$ & 28 \\
\hline \multirow[t]{2}{*}{$\mathrm{BaC} 574 / 577 \ldots$} & \multirow[t]{2}{*}{8171} & $\left\{\begin{array}{l}1 \\
2\end{array}\right.$ & $\begin{array}{l}\text { 2. } 904 \\
\text { 2. } 898 \\
\end{array}$ & $\begin{array}{l}2.914 \\
\text { 2. } 913 \\
\end{array}$ & $\begin{array}{l}\text { 2. } 934 \\
\text { 2. } 922 \\
\end{array}$ & $\begin{array}{l}2.951 \\
\text { 2. } 947 \\
\end{array}$ & ......... & ......... & ........ & $\begin{array}{c}3.180 \\
\end{array}$ & 21 \\
\hline & & avg $\ldots . . .$. & 2. 901 & 2. 914 & 2.928 & 2. 949 & ......... & ........ & $\ldots \ldots$ & …..... & (n........ \\
\hline \multirow[t]{2}{*}{$\mathrm{BaC} 6109 / 572$} & \multirow[t]{2}{*}{8250} & $\left\{\begin{array}{l}1 \\
2\end{array}\right.$ & $\begin{array}{l}\text { 3. } 207 \\
\text { 3. } 207 \\
\end{array}$ & $\begin{array}{l}\text { 3. } 222 \\
\text { 3. } 222 \\
\end{array}$ & $\begin{array}{l}\text { 3. } 249 \\
\text { 3. } 251 \\
\end{array}$ & $\begin{array}{l}\text { 3. } 278 \\
\text { 3. } 278 \\
\end{array}$ & -......... & -....... & ...... & $\begin{array}{c}3.518 \\
\end{array}$ & 30 \\
\hline & & avg $\ldots . . .$. & 3. 207 & 3. 222 & 3.250 & 3. 278 & ........ & $\ldots+\ldots$ & ........ & -....... & ......... \\
\hline \multirow[t]{2}{*}{$\mathrm{BaC} 611 / 588$} & \multirow[t]{2}{*}{7922} & $\left\{\begin{array}{l}1 \\
2\end{array}\right.$ & $\begin{array}{l}2.883 \\
2.884 \\
\end{array}$ & $\begin{array}{r}2.900 \\
2.902 \\
\end{array}$ & $\begin{array}{l}\text { 2. } 924 \\
\text { 2. } 924 \\
\end{array}$ & 2. 945 & ........ & ....... & ….... & $\begin{array}{r}3.177 \\
\end{array}$ & 27 \\
\hline & & avg ....... & 2. 884 & 2. 901 & 2. 924 & -....... & ........ & ........ & ........ & ........ & ......... \\
\hline $\mathrm{BaC} 617 / 550$ & 6903 & $1 \ldots$ & 3.363 & 3. 368 & 3.390 & 3.413 & $\ldots$ & $\ldots+\ldots$ & $\ldots$ & 3.652 & 23 \\
\hline \multirow[t]{2}{*}{$\mathrm{BaC} 620 / 600 \ldots$} & \multirow[t]{2}{*}{8085} & $\left\{\begin{array}{l}1 \\
2\end{array}\right.$ & $\begin{array}{l}\text { 3. } 089 \\
\text { 3. } 081 \\
\end{array}$ & $\begin{array}{l}\text { 3. } 120 \\
\text { 3. } 109 \\
\end{array}$ & $\begin{array}{l}\text { 3. } 154 \\
\text { 3. } 147 \\
\end{array}$ & $\begin{array}{l}\text { 3. } 196 \\
\text { 3. } 190 \\
\end{array}$ & $\begin{array}{c}3.224 \\
\end{array}$ & .1...... & ....... & $\begin{array}{r}3.490 \\
\end{array}$ & $\begin{array}{c}37 \\
\end{array}$ \\
\hline & & avg....... & 3.085 & 3.114 & 3. 150 & 3. 193 & ......... & ......... & ......... & ........ & .......... \\
\hline \multirow[t]{2}{*}{ BaF $584 / 460 \ldots$} & \multirow[t]{2}{*}{7631} & $\left\{\begin{array}{l}1 \\
2\end{array}\right.$ & $\begin{array}{l}\text { 3. } 067 \\
\text { 3. } 069 \\
\end{array}$ & $\begin{array}{l}\text { 3. } 084 \\
\text { 3. } 088 \\
\end{array}$ & $\begin{array}{l}\text { 3. } 087 \\
\text { 3. } 102 \\
\end{array}$ & $\begin{array}{l}\text { 3. } 109 \\
\text { 3. } 122\end{array}$ & ....... & ....... & ........ & $\begin{array}{r}3.286 \\
\end{array}$ & 15 \\
\hline & & avg......... & 3.068 & 3. 086 & 3. 094 & 3.116 & ......... & ......... & ......... & ......... & .......... \\
\hline \multirow[t]{2}{*}{ BaF $604 / 435 \ldots$} & \multirow[t]{2}{*}{3849} & $\left\{\begin{array}{l}1 \\
2 \\
3 \\
3 \\
4\end{array}\right.$ & $\begin{array}{l}\text { 3. } 265 \\
\text { 3. } 262 \\
3.221 \\
3.247 \\
\end{array}$ & $\begin{array}{l}\text { 3. } 281 \\
3.276 \\
3.236 \\
3.263 \\
\end{array}$ & $\begin{array}{l}\text { 3. } 296 \\
\text { 3. } 296 \\
\text { 3. } 253 \\
\text { 3. } 280 \\
\end{array}$ & $\begin{array}{l}\text { 3. } 321 \\
\text { 3. } 263 \\
\text { 3. } 301 \\
\end{array}$ & 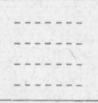 & 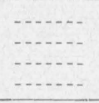 & 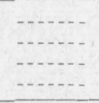 & \begin{tabular}{c}
3.488 \\
\hdashline$\ldots .$. \\
\\
\end{tabular} & $\begin{array}{c}16 \\
-16 \\
\end{array}$ \\
\hline & & avg ........ & 3. 249 & 3. 264 & 3. 281 & 3. 295 & ........ & ......... & ......... & ......... & $=$ \\
\hline $\mathrm{BaF} 605 / 435 \ldots$ & \multirow{3}{*}{$\begin{array}{l}7660 \ldots \\
6980\end{array}$} & $1 \ldots$ & 3. 267 & 3. 271 & 3. 296 & 3. 301 & …..... & …....... & ........... & 3.487 & …....... \\
\hline \multirow[t]{2}{*}{ LC $512 / 605 \ldots$} & & $\left\{\begin{array}{l}1 \\
2 \ldots \ldots \ldots\end{array}\right.$ & $\begin{array}{l}\text { 2. } 223 \\
\text { 2. } 223\end{array}$ & $\begin{array}{l}\text { 2. } 236 \\
\text { 2. } 241\end{array}$ & $\begin{array}{l}\text { 2. } 252 \\
\text { 2. } 257\end{array}$ & $\begin{array}{l}\text { 2. } 276 \\
\text { 2. } 272\end{array}$ & . & ........ & ........ & 2. 481 & $\begin{array}{c}26 \\
-\end{array}$ \\
\hline & & avg $\ldots \ldots$ & 2. 223 & 2. 238 & 2. 254 & 2. 274 & ......... & N....... & …..... & ........ & - \\
\hline \multirow[t]{2}{*}{ LC $523 / 586$} & 6988 & $\left\{\begin{array}{l}1 \\
2 \ldots \ldots\end{array}\right.$ & $\begin{array}{l}2.301 \\
\text { 2. } 302 \\
\end{array}$ & $\begin{array}{l}2.309 \\
2.313 \\
\end{array}$ & $\begin{array}{l}2.320 \\
2.323 \\
\end{array}$ & $\begin{array}{l}2.325 \\
2.334 \\
\end{array}$ & ......... & ....... & ......... & 2. 512 & 16 \\
\hline & & avg $\ldots . .$. & 2. 302 & 2. 311 & 2. 322 & 2. 330 & …n... & -...... & ........ & ....... & , \\
\hline BSC $511 / 635 \ldots$ & $7656 \ldots$ & $\left\{\begin{array}{l}1 \\
2\end{array}\right.$ & $\begin{array}{l}\text { 2. } 180 \\
\text { 2. } 177 \\
\end{array}$ & $\begin{array}{l}\text { 2. } 201 \\
\text { 2. } 203\end{array}$ & $\begin{array}{l}\text { 2. } 222 \\
\text { 2. } 221 .\end{array}$ & $\begin{array}{l}\text { 2. } 254 \\
\text { 2. } 247 \\
\end{array}$ & …..... & .......... & ............ & 2. 468 & $\begin{array}{c}34 \\
-\end{array}$ \\
\hline & & avg ....... & 2. 178 & 2. 202 & 2. 222 & 2. 250 & - & - & - & ........ & - \\
\hline BSC 517/645 & 8244 & $\left\{\begin{array}{l}1 \\
2 \\
2\end{array}\right.$ & $\begin{array}{l}\text { 2. } 221 \\
\text { 2. } 219 \\
\end{array}$ & $\begin{array}{l}\text { 2. } 236 \\
\text { 2. } 238 \\
\end{array}$ & $\begin{array}{l}2.259 \\
\text { 2. } 259 \\
\end{array}$ & $\begin{array}{l}\text { 2. } 278 \\
\text { 2. } 287\end{array}$ & - & an. & ........ & $\begin{array}{l}2.506 \\
\end{array}$ & $\begin{array}{c}35 \\
-\end{array}$ \\
\hline & & avg........ & 2. 220 & 2. 237 & 2. 259 & 2. 282 & $\ldots$ & ........ & ........ & ........ & $=$ \\
\hline BSC $517 / 645$ & 8097 & $\left\{\begin{array}{l}1 \\
2 \\
2\end{array}\right.$ & $\begin{array}{l}2.215 \\
2.211 \\
\end{array}$ & $\begin{array}{l}\text { 2. } 235 \\
\text { 2. } 228\end{array}$ & $\begin{array}{l}\text { 2. } 259 \\
\text { 2. } 252 \\
\end{array}$ & 2. 277 & 2.307 & (n) & ........ & $\begin{array}{r}2.497 \\
-\end{array}$ & 38 \\
\hline & & avg ....... & 2. 213 & 2. 232 & 2. 256 & $\ldots+\ldots$ & $\ldots \ldots \ldots$ & ........ & $\ldots \ldots$ & $\ldots$ & -........ \\
\hline BSC $517 / 645_{2}$ & $8223_{-}$ & $\left\{\begin{array}{l}1 \\
2\end{array}\right.$ & $\begin{array}{l}2.199 \\
2.185 \\
\end{array}$ & $\begin{array}{l}\text { 2. } 215 \\
\text { 2. } 215\end{array}$ & $\begin{array}{l}\text { 2. } 236 \\
\text { 2. } 231\end{array}$ & $\begin{array}{l}\text { 2. } 267 \\
\text { 2. } 263\end{array}$ & ....... & an. & ........ & (n....... & $\begin{array}{r}40 \\
-\end{array}$ \\
\hline & & avg $\ldots . .$. & 2. 192 & 2. 215 & 2. 234 & 2. 265 & ........ & ........ & ......... & ......... & W........ \\
\hline BSC $540 / 645$ & 6471 & $1 \ldots$ & 2. 269 & 2. 272 & 2. 292 & 2.316 & 2.341 & , n...... & -...-. & 2. 561 & 37 \\
\hline
\end{tabular}

\section{Volumeter Method}

Figure 10 shows a plot of the data obtained with the volumeter on $\mathrm{BaF}$ 604. In this instance the data obtained in both the cooling and heating schedules showed good agreement. In other cases where the agreement between the two schedules was not good, the difference was traced to devitrification. An estimate of the liquidus temperature of the glass could be made from study of the density data. The sharp drop in density occurring at about $1,350^{\circ} \mathrm{C}$ was probably due to the formation of bubbles in the glass. It was noted that the surface of the melt was covered with fairly large bubbles and could not be freed from them by stirring as long as the temperature was above $1,350^{\circ} \mathrm{C}$. Below this temperature the bubbles were observed to disappear gradually, first receding to the periphery of the crucible, leaving a clear area in the middle, and then disappearing for the most part. The increase in slope of the density-temperature curve below about $950^{\circ} \mathrm{C}$ is suspected to be caused by nonuni- 


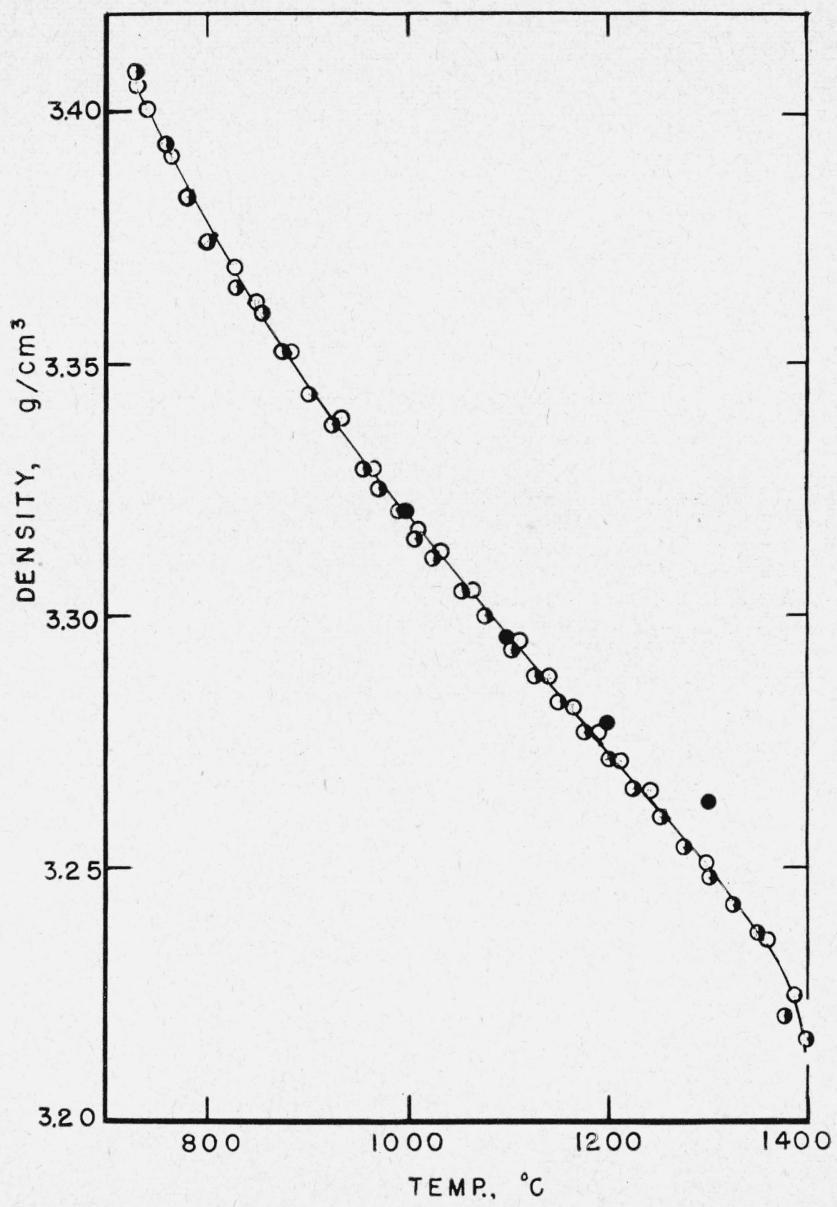

Figure 10. Density of $\mathrm{BaF} 604 / 435$ versus Centigrade temperature.

Half-filled circles show volumeter data obtained on $50^{\circ} \mathrm{C} /$ hour cooling schedule, open circles show volumeter data on reheating in 25-deg C steps, both on Melt 3354. Filled circles represent sphere data on Melt 3849, which is of the same nominal composition (see table 1).

form drainage of the highly viscous glass in this temperature range. For these reasons only the density data in the region between $950^{\circ}$ and $1,200^{\circ} \mathrm{C}$ are considered reliable. ${ }^{4}$

The points enclosed by filled circles (fig. 10) represent the density data obtained by the counterbalanced sphere method on the same kind of glass from a different pot. However the nominal compositions are identical, and thus a comparison between the two methods is possible. Between $1,000^{\circ}$ and $1,200^{\circ} \mathrm{C}$ the agreement is excellent. At $1,300^{\circ} \mathrm{C}$ the ball method yielded high values. At this temperature there are probably a few small seeds (bubbles) in the melt, but their presence should not cause much error in the volumeter method; the

${ }^{4}$ For those who may wish to use this or a similar method for obtaining accurate densities, it is suggested that the glass be covered with a layer of a molten salt. The volume-temperature relationships of such a salt have to be known or determined, and of course one should be picked that will not severely attack the glass. The high fluidity of most molten salts is such that they will readily drain off the walls of the crucible and thus allow density measurements to extend to lower temperatures than are possible without their use. High accuracy in the knowledge of the volume-temperature relationship of the salt is not necessary, as only a relatively small amount need be used. error should be in the direction of too large a volume and hence too low a density. In the case of the ball method, a bubble that attaches itself to the ball will make the ball appear to be lighter; hence the buoyant effect will appear too large, and too great a density will be calculated. Figure 11 shows another comparison between the ball and volumeter methods on two glasses of nominally identical compositions. Here, also, the value at $1,300^{\circ}$ is too high. Other glasses measured by both methods are not comparable because of differences in composition.

Table 9 gives the data that were obtained by the volumeter method over the range where such data were considered reliable. The agreement between nominally duplicate measurements is satisfactory. It is probable that the temperature coefficient of density over the range where such data are valid is more reliable than similar data obtained with the ball method because the volumeter method is intrinsically a differential method.

As expansivity data for some glasses were available in both the low $\left(25^{\circ}\right.$ to $\left.600^{\circ} \mathrm{C}\right)$ and high $\left(900^{\circ}\right.$ to $1,300^{\circ} \mathrm{C}$ ) temperature ranges, the total expansion curve in the range from $25^{\circ}$ to $1,300^{\circ} \mathrm{C}$ could be constructed (fig. 12). The lower part of figure 12 shows a plot of the expansivity of BSC $517 / 64.5$. The data from room temperature to the softening point were obtained on a sample from Melt 3246 by J. B. Saunders [10] with an interferometer method. The data on a sample from Melt 3703 from $900^{\circ} \mathrm{C}$ and above were obtained with the volumeter. The two filled circles represent the mean expansivity over a 200-deg C interval plotted at the midpoint. The broken line indicates the interpolation that was adopted. The continuation of the open circles below $P$ indicates the observed slumping of the specimen. The curve in the upper part of figure 12 was obtained by integration of the expansivity curve. The open and half-filled circles represent two different determinations with the volumeter. At the lower temperatures where the data are unreliable because of poor drainage the half-filled circles show the direction of the error from this cause.

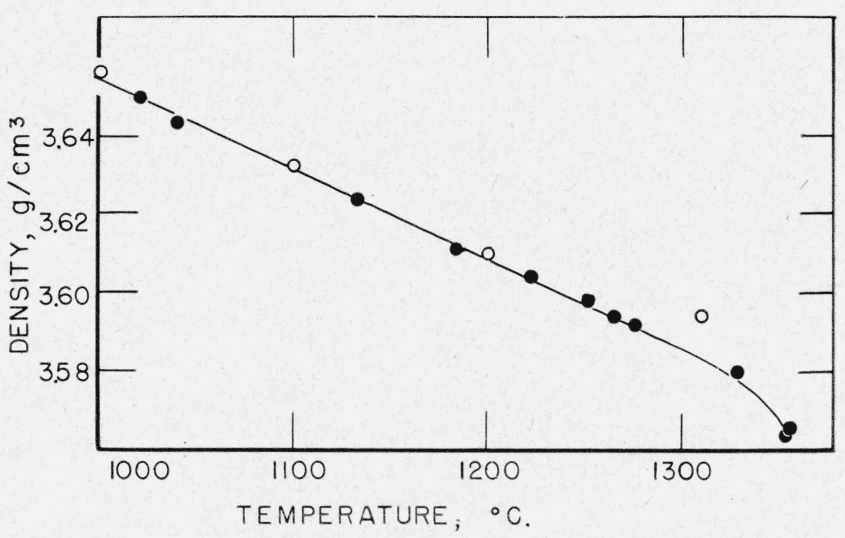

Figure 11. Density of F 649/39.8 versus temperature.

Curve represents volumeter data on Melt 5943 (filled circles), and open circles represent sphere data on Melt 8187 . These melts have nominally identical composition (table 1). 
TABLE 9. Density and expansivity of optical glasses by volumeter method

$\mathrm{F}=$ flint $; \mathrm{BaC}=$ barium crown $; \mathrm{BaF}=$ barium flint; $\mathrm{BSC}=$ borosilicate crown

\begin{tabular}{|c|c|c|c|c|c|c|c|c|c|}
\hline \multirow{2}{*}{ Glass } & \multirow{2}{*}{ Melt } & \multicolumn{7}{|c|}{ Density $\left(\mathrm{g} / \mathrm{cm}^{3}\right)$ at } & \multirow{2}{*}{$\begin{array}{l}\text { Expan- } \\
\text { sivity }\end{array}$} \\
\hline & & $1300^{\circ} \mathrm{C}$ & $1200^{\circ} \mathrm{C}$ & $1100^{\circ} \mathrm{C}$ & $1000^{\circ} \mathrm{C}$ & $900^{\circ} \mathrm{C}$ & $800^{\circ} \mathrm{C}$ & Room & \\
\hline \multirow[t]{2}{*}{$\begin{array}{l}\text { F. } 620 / 362 \\
\text { F } 649 / 338 \\
\text { BaF } 588 / 534\end{array}$} & $\begin{array}{l}5747 \ldots \\
5943 \ldots \\
3800 \ldots\end{array}$ & $\begin{array}{l}3.360 \\
3.587 \\
2.996 \\
3.000 \\
2.999\end{array}$ & $\begin{array}{l}3.380 \\
3.609 \\
3.024 \\
\text { 3. } 027 \\
3.025\end{array}$ & $\begin{array}{l}3.402 \\
\text { 3. } 631 \\
\text { 3. } 052 \\
3.055 \\
\text { 3. } 053\end{array}$ & $\begin{array}{l}\text { 3. } 423 \\
\text { 3. } 654 \\
\text { 3. } 082 \\
\text { 3. } 087 \\
\text { 3. } 085\end{array}$ & $\begin{array}{l}3.446 \\
3.678 \\
3.118 \\
3.120 \\
3.119\end{array}$ & \begin{tabular}{l}
3.470 \\
\hdashline-1.0 \\
$-\cdots$
\end{tabular} & 3.317 & $\begin{array}{c}(\mu / m) /{ }^{\circ} C \\
21 \\
21 \\
34 \\
\\
\end{array}$ \\
\hline & avg & 2. 998 & 3. 025 & 3.053 & 3.085 & 3.119 & -....... & - - & - n..... \\
\hline \multirow[t]{2}{*}{ BaF $604 / 435$} & 3354 & $\left\{\begin{array}{l}3.259 \\
3.249\end{array}\right.$ & $\begin{array}{l}\text { 3. } 273 \\
\text { 3. } 272\end{array}$ & $\begin{array}{l}\text { 3. } 296 \\
3.294\end{array}$ & $\begin{array}{l}3.319 \\
3.317\end{array}$ & $\begin{array}{l}3.346 \\
3.342\end{array}$ & $\begin{array}{l}3.376 \\
3.366\end{array}$ & 3.483 & 23 \\
\hline & avg & 3.254 & 3.272 & 3.295 & 3.318 & 3. 344 & 3.371 & - n..... & - \\
\hline \multirow[t]{2}{*}{$\mathrm{BaC} 5725 / 574 \ldots \ldots$} & 3247 & $\left\{\begin{array}{l}2.936 \\
2.933\end{array}\right.$ & $\begin{array}{l}2.959 \\
2.958\end{array}$ & $\begin{array}{l}2.979 \\
2.984\end{array}$ & $\begin{array}{l}3.008 \\
3.016\end{array}$ & $\begin{array}{r}3.039 \\
-\end{array}$ & - & 3.201 & $\begin{array}{c}26 \\
-\end{array}$ \\
\hline & avg .... & 2. 934 & 2.958 & 2.982 & 3.012 & - n & .......... & ........ & ......... \\
\hline \multirow[t]{2}{*}{$\begin{array}{l}\mathrm{BaC} 5725 / 574 \\
\mathrm{BSC} 517 / 645\end{array}$} & $\begin{array}{l}3722 \ldots \\
3703 \ldots\end{array}$ & $\left\{\begin{array}{l}2.915 \\
2.199 \\
2.196\end{array}\right.$ & $\begin{array}{l}2.938 \\
2.226 \\
2.228\end{array}$ & $\begin{array}{l}\text { 2. } 968 \\
\text { 2. } 261 \\
\text { 2. } 257\end{array}$ & $\begin{array}{l}\text { 2. } 994 \\
\text { 2. } 294 \\
\text { 2. } 293\end{array}$ & $\begin{array}{l}3.028 \\
-\end{array}$ & (n) & 2.505 & $\begin{array}{r}31 \\
47 \\
-\end{array}$ \\
\hline & avg...... & 2. 198 & 2.227 & 2. 259 & 2.294 & -.. & - n. & - n. & $\ldots$ \\
\hline
\end{tabular}
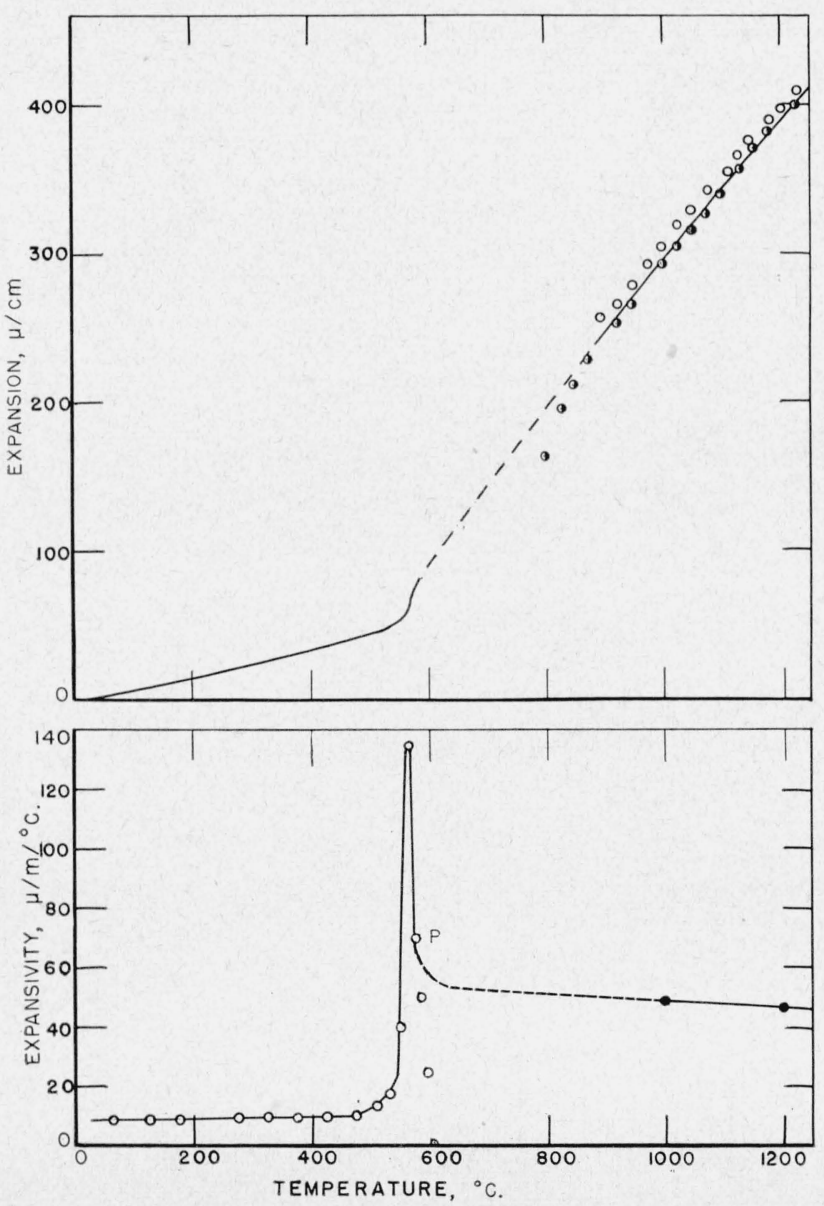

FIgURE 12. Thermal expansion and expansivity of BSC $517 / 64.5$ as a function of temperature.

Data from room to approxirnately $600^{\circ} \mathrm{C}$ on Melt 3246 by interferometer method. Data above $800^{\circ} \mathrm{C}$ on Melt 3703 by volumeter method. Each of the two filled circles represents the mean expansivity over a 200-deg C interval plotted at the midpoint.
Two features of interest may be noted concerning the expansivity curve. One is that although the expansivity in the low temperature range increases with temperature, the reverse relationship seems to hold in the liquid range. The second point of interest is that the expansivity shows a decrease before the interferometer softening point is reached that is not due to slumping of the specimen.

Saunders was able to demonstrate this point in an ingenious experiment. He used a plane parallel polished specimen plate with a hole in the center. This plate was placed between two fused silica flats in such manner that interference fringes could be observed through the air space in the hole, as well as between the polished faces of the specimen itself. The conditions were such that the pressure of the upper silica flat was negligible. Figure 13 shows a plot of the results obtained. In the temperature region $650^{\circ}$ to $690^{\circ} \mathrm{C}$ there occurs a slowing down of the precipitous drop of the expansion coefficient. In this temperature range the specimen did not slump as judged by the appearance of the interference fringes between the polished faces of the specimen. The dashed line indicates the probable further course of the expansion coefficient if the specimens had not slumped from this region onward. The sharp drop in expansion coefficient actually observed beyond the $650^{\circ}$ to $690^{\circ} \mathrm{C}$ region was due to slumping of the specimen plate as evidenced by the curving of the interference fringes between the faces of the specimen.

\section{Discussion}

Data on viscosity and density of glass melts are of value in explaining molding properties of glasses, behavior to stirring and fining during the melting cycle, performance of the glass as it is cooled, etc. The data also indicate class difference in expansivity among the major types of optical glasses. Because 


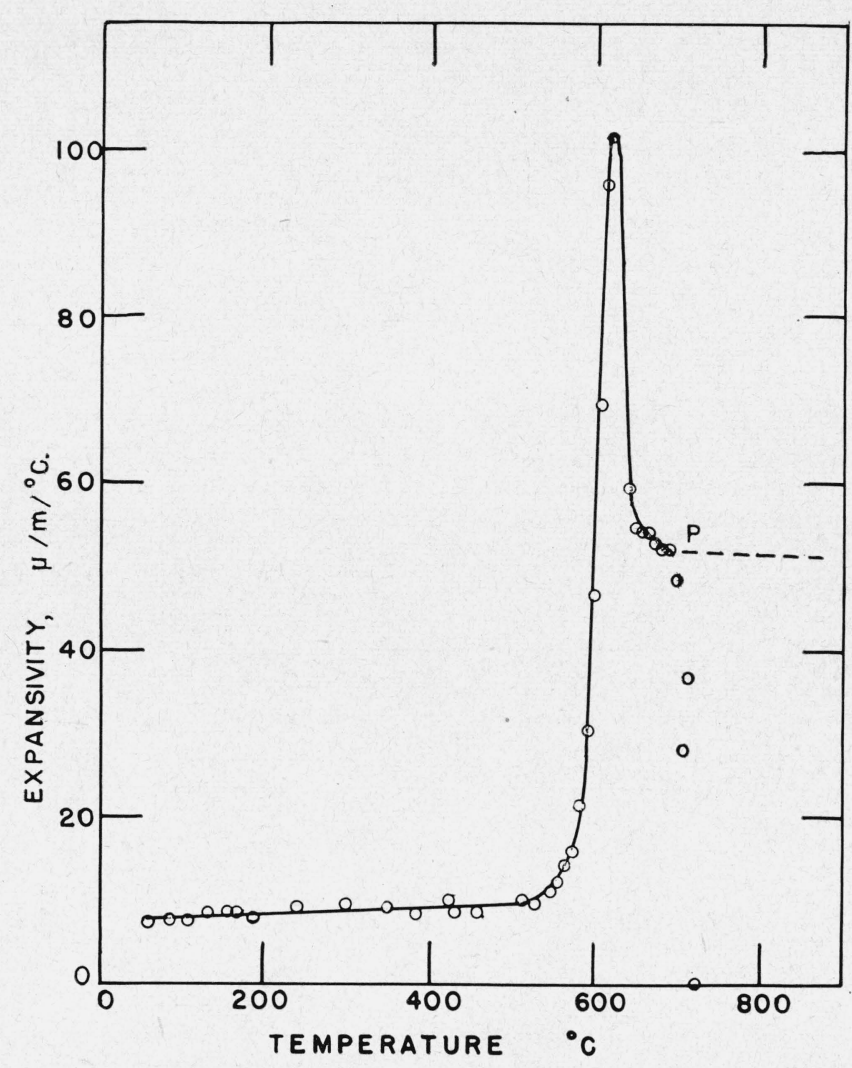

Figure 13. Thermal expansivity of BSC 517/64.5.

of the lack of systematic variation in composition of the glasses studied, it is not possible, however, to establish close correlation of viscometric and density data with composition. Further, as viscosity curves may cross, a statement regarding one temperature region may be invalid in another region. Figure 14 illustrates this point. Here $\mathrm{BaC} 620$ is less viscous at $1,300^{\circ} \mathrm{C}$ and more viscous at $850^{\circ} \mathrm{C}$ than any of the other glasses represented. In general, when comparing the viscosity of glasses it is necessary to compare viscosity versus temperature relationships.

\section{Temperature Coefficient of Viscosity and Molding of Glass}

The slope of the viscosity-temperature curve is a property in which the glass technologist is very much interested. In general, the optical flints as a group show relatively small slopes; that is, the viscosity does not change rapidly with temperature, whereas barium crowns as a group show relatively large slopes. This is related to the ease with which these glasses may be formed or pressed, as will be shown.

The practical glassworker calls a glass that he can form or shape with ease a "sweet," or "long," glass. If, while he works with the glass, it stiffens so that he has to reheat frequently, he calls it a "sour," or "short," glass. Sweetness and sourness of glass depend upon the rate of cooling, which is a complicated function of the temperature, the size of the piece, the color, etc. Thus, if two glasses at the same initial temperature were cooled at the same rate, sweetness would be inversely related to the slope of the viscosity-temperature curve. The glass with a viscosity that changed slowly with fall in temperature would be in the proper viscosity range for easy working for a longer time than the sour glass with a rapid change of viscosity with temperature.

The slope of the viscosity-temperature curve is, however, not the only factor in practical rating of sweetness and sourness. Glass is taken from the furnace at the top of its working range. Other things being equal, the glass with working range in a higher temperature region will cool faster and therefore be more sour.

An attempt was made to evaluate the molding qualities of the glasses by taking into account the temperature difference between two selected viscosities and dividing that by the square of the higher temperature. The two viscosities selected were $\log \eta=2.5$ and 3.5. These viscosities are in the range for lamp working and were selected because such data were available on a great many optical glasses. As cooling of the glass takes place by radiation as well as conduction, the square of the temperature was selected on a trial basis. Table 10 shows the data obtained. The sweetness index $\left(T_{1}-T_{2}\right) /\left(T_{1}^{2}\right)$ is seen to be high for the optical flints, low for the barium crowns, and intermediate for the others. In order to test the validity of this concept of sweetness index with practical observation, a questionnaire was submitted to five molding crew supervisors who were asked to place 22 glass types in order of increasing difficulty in pressing optical lens blanks. A rank correlation of +0.93 was found between the average order as estimated by the supervisors and that calculated from the sweetness index.

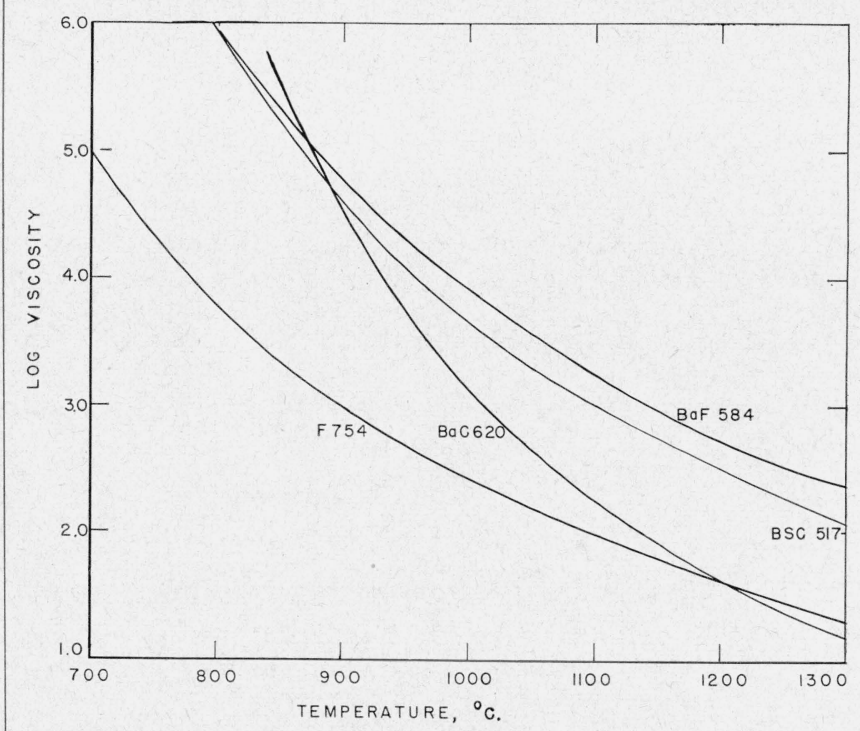

FIGURE 14. Curves of log viscosity versus temperature of some typical optical glasses. 
TABLE 10. Some properties of optical glasses

\begin{tabular}{|c|c|c|c|c|c|c|c|}
\hline Glass & Melt & $\begin{array}{l}T_{1} \text { at } \\
\log \eta \\
=2.5\end{array}$ & $\begin{array}{l}T_{2} \text { at } \\
\log \eta \\
=3.5\end{array}$ & $\begin{array}{c}T_{1}- \\
T_{2}\end{array}$ & $\begin{array}{c}\begin{array}{c}\text { Sweet- } \\
\text { ness } \\
\text { index, } \\
T_{1}-T_{2} \\
T_{1}{ }^{2}\end{array}\end{array}$ & $\begin{array}{c}\text { Ex- } \\
\text { pan- } \\
\text { siv- } \\
\text { ity } \\
\left(1,000^{\circ}\right. \\
\text { to } \\
1,200^{\circ} \\
C),\end{array}$ & $\begin{array}{c}\text { Slope of } \\
\log \eta \text { vs. } \\
\text { tempera- } \\
\text { ture, } \\
\frac{1}{T_{1}-T_{2}}\end{array}$ \\
\hline & & ${ }^{\circ} \mathrm{C}$ & ${ }^{\circ} \mathrm{C}$ & ${ }^{\circ} C$ & & $\left(\mu_{0} / m\right) /$ & \\
\hline F $5795 / 410$ & 7133 & 1,302 & 1,083 & 219 & $129 \times 10^{-6}$ & 16 & $456 \times 10^{-5}$ \\
\hline F $617 / 366$ & 7045 & 1,115 & 922 & 193 & 155 & 19 & 518 \\
\hline F $620 / 362$ & 8197 & 1,162 & 964 & 198 & 146 & 19 & 505 \\
\hline F $649 / 338 \ldots$ & $\begin{array}{r}8187 \\
\& 9\end{array}$ & 1,150 & 957 & 193 & 146 & 20 & 518 \\
\hline F $666 / 324 \ldots \ldots$ & 7686 & 1,140 & 950 & 190 & 146 & 20 & 526 \\
\hline F $689 / 309$. & 7382 & 1,111 & 931 & 180 & 146 & 18 & 556 \\
\hline F $720 / 293$. & 7728 & 1,054 & 887 & 167 & 150 & 20 & 599 \\
\hline F $754 / 277$. & 8001 & 988 & 838 & 150 & 157 & 22 & 667 \\
\hline CF $529 / 516$ & 8217 & 1,236 & 1,022 & 214 & 140 & 16 & 467 \\
\hline $\mathrm{BaC} 541 / 599 \ldots$ & 8072 & 1,254 & 1,064 & 190 & 121 & 25 & 526 \\
\hline $\mathrm{BaC} 5725 / 574 \ldots$ & 4581 & 1,181 & 1,020 & 161 & 115 & 28 & 621 \\
\hline BaC 574/577. & 8171 & 1,196 & 1,040 & 156 & 116 & 21 & 641 \\
\hline $\mathrm{BaC} 6109 / 572$ & 8250 & 1,147 & 1,021 & 126 & 96 & 30 & 794 \\
\hline $\mathrm{BaC} 611 / 588 \ldots$ & 7922 & 1,198 & 1,037 & 161 & 112 & 27 & 621 \\
\hline $\mathrm{BaC} 617 / 550 \ldots$ & 6903 & 1,162 & 1,028 & 134 & 99 & 23 & 746 \\
\hline $\mathrm{BaC} 620 / 600$ & 8085 & 1,068 & 970 & 98 & 86 & 37 & 1020 \\
\hline BaF $584 / 460$ & 7631 & 1,262 & 1,065 & 197 & 124 & 15 & 507 \\
\hline BaF $604 / 435$ & 3849 & 1,228 & 1,055 & 173 & 115 & 16 & 578 \\
\hline BSC $511 / 635 \ldots$ & 7656 & 1,190 & 1,012 & 178 & 125 & 34 & 561 \\
\hline BSC $517 / 645$. & 8097 & 1,180 & 1,012 & 168 & 120 & 38 & 595 \\
\hline BSC $517 / 645 \ldots$ & 8244 & 1,206 & 1,026 & 180 & 124 & 35 & 556 \\
\hline BSC $517 / 645 \ldots$ & 8223 & 1,181 & 1,014 & 168 & 120 & 40 & 595 \\
\hline BSC $540 / 645 \ldots$ & 6471 & 1,074 & 919 & 155 & 134 & 37 & 645 \\
\hline LC $512 / 605$ & 6980 & 1,206 & 1,014 & 192 & 132 & 26 & 521 \\
\hline LC $523 / 586 \ldots$ & 6988 & 1,238 & 1,043 & 195 & 127 & 16 & 513 \\
\hline
\end{tabular}

\section{Expansivity and Temperature Coefficient of Viscosity}

The last two columns of table 10 give the expansivity (col. 7) in the liquid range (approximately $1,000^{\circ}$ to $1,200^{\circ} \mathrm{C}$ ) as calculated from density data, as well as the slope (col. 8) of the curve of $\log \eta$ versus temperature in the region between $\log \eta=2.5$ and 3.5 . Figure 15 shows a plot of these data. There is a general correlation indicating a common factor in these two properties. This common factor may be the change in attractive force between molecules or molecular groupings with change in temperature. As we are dealing with many kinds of groupings, the correlation cannot be expected to be high. The flints are found in the lower left hand part of figure 15, and within the group there is a general tendency for the slope to increase with the expansivity. Similarly, the barium crowns as a group are found in the central part of the diagram and also show a tendency for the slope to increase with increasing expansivity. The borosilicate crowns as a group show the highest expansivities accompanied by only moderate slopes, and within the group there is some trend for the slope to increase with expansivity.

\section{Expansivity and "Breaks"}

In the transfer process of making optical glass, [11] the proper cooling of the pot of glass after removal from the melting furnace is of the utmost importance in order for the glass to break into large usable pieces. In the case of flints, cooling at $18 \mathrm{deg} \mathrm{C} / \mathrm{hr}$ through the critical temperature region (where the rapid expansion region begins, fig. 12) results in sat-

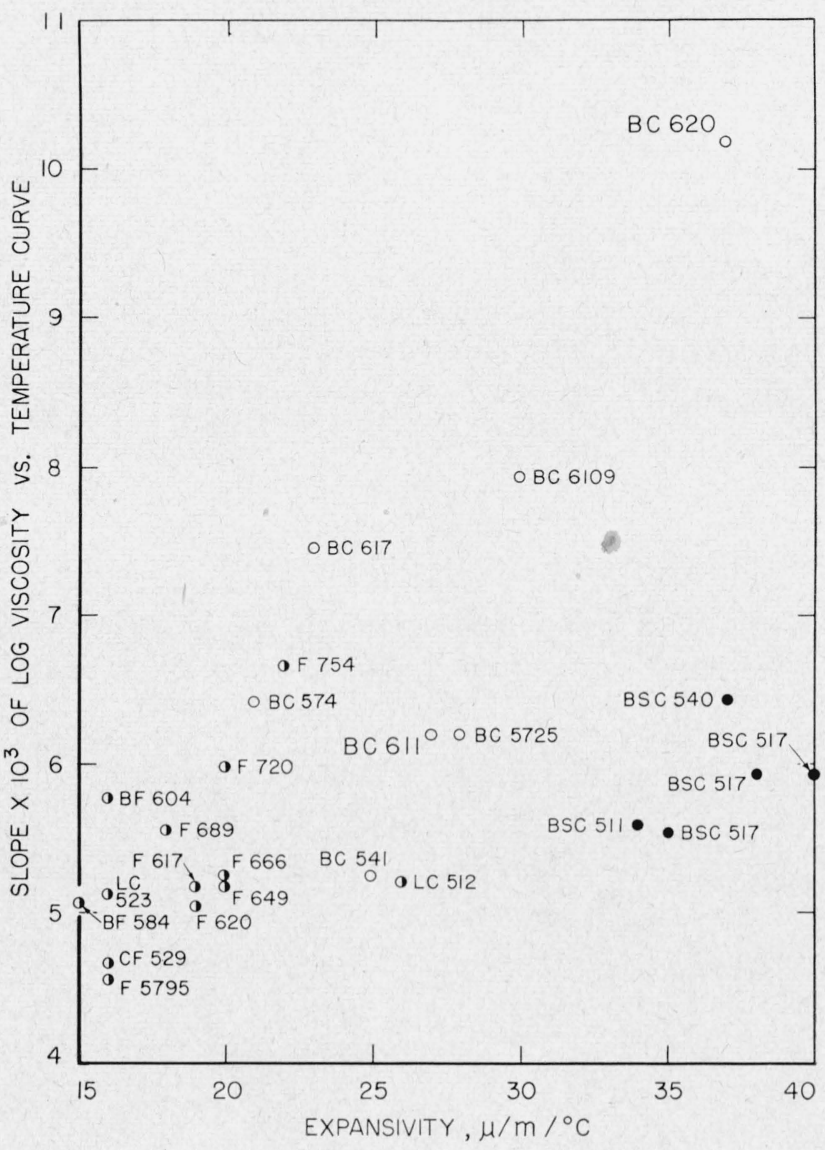

FIGURE 15. Expansivity versus the slope of the viscosity-temperature curve.

isfactory breaks, whereas the same procedure causes unsatisfactory results (vacuum bubbles, shattering, onions [11]) when applied to borosilicate crowns [12]. For satisfactory breaks with borosilicates the cooling rate has to be lowered to at least $16 \mathrm{deg} \mathrm{C} / \mathrm{hr}$. It seems probable that this difference in behavior is partially accounted for by the lower expansivity of the flints in the liquid range as compared to that of the borosilicates. As the pot is cooled, the surface of the glass reaches a temperature at which it becomes rigid while the glass in the hotter interior is still fairly liquid. With further cooling the glass in the center of the pot tries to contract much more than the rigid surface glass (because it has a higher expansion, fig. 12) thus producing some of the stresses that break the glass. As the ratio of the expansivities in the liquid region to that in the solid region is much less for flints than for borosilicates, the flints can endure a greater cooling rate than the borosilicates and still produce satisfactory breaks.

\section{Summary and Conclusion}

1. Viscosities and densities of molten optical glasses were measured with a counterbalancedsphere method. The sphere apparatus is simple, rugged, and has stood up well with continued use. 
2. The densities obtained with the sphere method agree well in the temperature range $1,000^{\circ}$ to $1,200^{\circ}$ $\mathrm{C}$ with those obtained by measuring the volume of a given weight of glass contained in a platinum volumetric flask.

3. Comparison of viscosity results obtained with the sphere method and a rotation viscometer has shown good agreement.

4. Expansivities calculated from density results obtained with the sphere method in the temperature range $1,000^{\circ}$ to $1,200^{\circ} \mathrm{C}$ indicate that the expansivity in this range is from 2 to 3.5 times that in the solid range $\left(100^{\circ}\right.$ to $\left.400^{\circ} \mathrm{C}\right)$. The flints and barium flints as a group have the lowest expansivity, the barium crowns are intermediate, and the borosilicate crowns have the highest expansivities. A correlation was found between expansivity in the liquid range and the slope of the viscosity-temperature curve.

5. A numerical value for the ease of making optical glass pressing was calculated from viscosity data. This index was found to correlate well with estimates made by molding supervisors.

6 . The Faxen correction of Stokes law was found to be superior to the Francis formula.

\section{References}

[1] L. R. Bacon, J. Frank Inst. 221, 251 (1936).

[2] A. W. Francis, Physics 4, 403 (1933).

[3] C. S. Cragoe, World Petroleum Congress 2, 529 (1933).

[4] V. H. Stott, E. Irvine, and D. Turner, Proc. Roy. Soc. (London) [A], 108, 154 (1925).

[5] G. Heidtkamp and K. Endell, Glastech. Ber. 14, 89 (1936).

[6] William N. Harrison, Robert E. Stephens, and Stephen M. Shelton, J. Research NBS 20, 39 (1938) RP1063.

[7] Leo Shartsis and Alden W. Smock, J. Research NBS 38, 341 (1947) RP1771.

[8] L. Wilhelmy, Pogg. Ann. 119, 177 (1863).

[9] James P. Poole and Maxwell Gensamer, J. Am. Ceram. Soc. 32, 220 (1949).

[10] J. B. Saunders, Private communication.

[11] Manufacture of Optical Glass and of Optical Glass Systems, Ordnance Dept. Document No. 2037 (1921).

[12] D. Hubbard, Private communication.

Washington, October 5, 1950. 